\title{
Optimized Vegetation Density to Dissipate Energy of Flood Flow in Open Canals
}

\author{
Mahdi Feizbahr $\mathbb{D}$, ${ }^{1}$ Navid Tonekaboni $\mathbb{D}^{2},{ }^{2}$ Guang-Jun Jiang $\mathbb{D},{ }^{3,4}$ and Hong-Xia Chen $\mathbb{D}^{3,4}$ \\ ${ }^{1}$ School of Civil Engineering, Engineering Campus, Universiti Sains Malaysia, 14300 Nibong Tebal, Penang, Malaysia \\ ${ }^{2}$ Mechanical-Energy Conversion, Islamic Azad University, Nour Branch, Nour, Iran \\ ${ }^{3}$ School of Mechanical Engineering, Inner Mongolia University of Technology, Hohhot, Inner Mongolia 010051, China \\ ${ }^{4}$ Inner Mongolia Key Laboratory of Advanced Manufacturing Technology, Hohhot, Inner Mongolia 010051, China \\ Correspondence should be addressed to Guang-Jun Jiang; jianggj_2003@163.com
}

Received 8 April 2021; Revised 18 June 2021; Accepted 17 July 2021; Published 11 August 2021

Academic Editor: Mohammad Yazdi

Copyright $\odot 2021$ Mahdi Feizbahr et al. This is an open access article distributed under the Creative Commons Attribution License, which permits unrestricted use, distribution, and reproduction in any medium, provided the original work is properly cited.

\begin{abstract}
Vegetation along the river increases the roughness and reduces the average flow velocity, reduces flow energy, and changes the flow velocity profile in the cross section of the river. Many canals and rivers in nature are covered with vegetation during the floods. Canal's roughness is strongly affected by plants and therefore it has a great effect on flow resistance during flood. Roughness resistance against the flow due to the plants depends on the flow conditions and plant, so the model should simulate the current velocity by considering the effects of velocity, depth of flow, and type of vegetation along the canal. Total of 48 models have been simulated to investigate the effect of roughness in the canal. The results indicated that, by enhancing the velocity, the effect of vegetation in decreasing the bed velocity is negligible, while when the current has lower speed, the effect of vegetation on decreasing the bed velocity is obviously considerable.
\end{abstract}

\section{Introduction}

Considering the impact of each variable is a very popular field within the analytical and statistical methods and intelligent systems [1-14]. This can help research for better modeling considering the relation of variables or interaction of them toward reaching a better condition for the objective function in control and engineering [15-27]. Consequently, it is necessary to study the effects of the passive factors on the active domain [28-36]. Because of the effect of vegetation on reducing the discharge capacity of rivers [37], pruning plants was necessary to improve the condition of rivers. One of the important effects of vegetation in river protection is the action of roots, which cause soil consolidation and soil structure improvement and, by enhancing the shear strength of soil, increase the resistance of canal walls against the erosive force of water. The outer limbs of the plant increase the roughness of the canal walls and reduce the flow velocity and deplete the flow energy in vicinity of the walls.
Vegetation by reducing the shear stress of the canal bed reduces flood discharge and sedimentation in the intervals between vegetation and increases the stability of the walls [38-41].

One of the main factors influencing the speed, depth, and extent of flood in this method is Manning's roughness coefficient. On the other hand, soil cover [42], especially vegetation, is one of the most determining factors in Manning's roughness coefficient. Therefore, it is expected that those seasonal changes in the vegetation of the region will play an important role in the calculated value of Manning's roughness coefficient and ultimately in predicting the flood wave behavior [43-45]. The roughness caused by plants' resistance to flood current depends on the flow and plant conditions. Flow conditions include depth and velocity of the plant, and plant conditions include plant type, hardness or flexibility, dimensions, density, and shape of the plant [46]. In general, the issue discussed in this research is the optimization of flood-induced flow in canals 
by considering the effect of vegetation-induced roughness. Therefore, the effect of plants on the roughness coefficient and canal transmission coefficient and in consequence the flow depth should be evaluated $[47,48]$.

Current resistance is generally known by its roughness coefficient. The equation that is mainly used in this field is Manning equation. The ratio of shear velocity to average current velocity $(V * / V)$ is another form of current resistance. The reason for using the $(V * / V)$ ratio is that it is dimensionless and has a strong theoretical basis. The reason for using Manning roughness coefficient is its pervasiveness. According to Freeman et al. [49], the Manning roughness coefficient for plants was calculated according to the Kouwen and Unny [50] method for incremental resistance. This method involves increasing the roughness for various surface and plant irregularities. Manning's roughness coefficient has all the factors affecting the resistance of the canal. Therefore, the appropriate way to more accurately estimate this coefficient is to know the factors affecting this coefficient [51].

To calculate the flow rate, velocity, and depth of flow in canals as well as flood and sediment estimation, it is important to evaluate the flow resistance. To determine the flow resistance in open ducts, Manning, Chézy, and Dar$c y-W e i s b a c h$ relations are used [52]. In these relations, there are parameters such as Manning's roughness coefficient $(n)$, Chézy roughness coefficient $(C)$, and Darcy-Weisbach coefficient $(f)$. All three of these coefficients are a kind of flow resistance coefficient that is widely used in the equations governing flow in rivers [53].

The three relations that express the relationship between the average flow velocity $(V)$ and the resistance and geometric and hydraulic coefficients of the canal are as follows:

$$
\begin{aligned}
& V=\frac{K_{n}}{n} R^{(2 / 3)} S_{f}^{(1 / 2)}, \quad \text { Manning, } \\
& V=\sqrt{\frac{8 g}{f}} \sqrt{R S_{f}}, \quad \text { Darcy - Weisbach, } \\
& V=C \sqrt{R S_{f}}, \quad \text { Chezy, }
\end{aligned}
$$

where $n, f$, and $c$ are Manning, Darcy-Weisbach, and Chézy coefficients, respectively. $V=$ average flow velocity, $R=$ hydraulic radius, $S_{f}=$ slope of energy line, which in uniform flow is equal to the slope of the canal bed, $g$ = gravitational acceleration, and $K_{n}$ is a coefficient whose value is equal to 1 in the SI system and 1.486 in the English system. The coefficients of resistance in equations (1) to (3) are related as follows:

$$
\sqrt{\frac{f}{8}}=\frac{n}{R^{(1 / 6)}} \frac{\sqrt{g}}{K_{n}}=\frac{\sqrt{g}}{C}=\frac{\sqrt{g R S_{f}}}{V} .
$$

Based on the boundary layer theory, the flow resistance for rough substrates is determined from the following general relation:

$$
\sqrt{\frac{8}{f}}=2.5 \operatorname{Ln} \frac{y}{K_{s}}+A
$$

where $f=$ Darcy-Weisbach coefficient of friction, $y=$ flow depth, $K_{s}=$ bed roughness size, and $A=$ constant coefficient.

On the other hand, the relationship between the Darcy-Weisbach coefficient of friction and the shear velocity of the flow is as follows:

$$
\sqrt{\frac{8}{f}}=\frac{V}{U^{*}}
$$

By using equation (6), equation (5) is converted as follows:

$$
\sqrt{\frac{8}{f}}=\frac{V}{U^{*}} 2.5 \operatorname{Ln} \frac{y}{K_{s}}+A .
$$

Investigation on the effect of vegetation arrangement on shear velocity of flow in laboratory conditions showed that, with increasing the shear Reynolds number $\left(\mathrm{Re}^{*}\right)$, the numerical value of the $V / U^{*}$ ratio also increases; in other words the amount of roughness coefficient increases with a slight difference in the cases without vegetation, checkered arrangement, and cross arrangement, respectively [54].

Roughness in river vegetation is simulated in mathematical models with a variable floor slope flume by different densities and discharges. The vegetation considered submerged in the bed of the flume. Results showed that, with increasing vegetation density, canal roughness and flow shear speed increase and with increasing flow rate and depth, Manning's roughness coefficient decreases. Factors affecting the roughness caused by vegetation include the effect of plant density and arrangement on flow resistance, the effect of flow velocity on flow resistance, and the effect of depth $[45,55]$.

One of the works that has been done on the effect of vegetation on the roughness coefficient is Darby [56] study, which investigates a flood wave model that considers all the effects of vegetation on the roughness coefficient. There are currently two methods for estimating vegetation roughness. One method is to add the thrust force effect to Manning's equation $[47,57,58]$ and the other method is to increase the canal bed roughness (Manning-Strickler coefficient) [45, 59-61]. These two methods provide acceptable results in models designed to simulate floodplain flow. Wang et al. [62] simulate the floodplain with submerged vegetation using these two methods and to increase the accuracy of the results, they suggested using the effective height of the plant under running water instead of using the actual height of the plant. Freeman et al. [49] provided equations for determining the coefficient of vegetation roughness under different conditions. Lee et al. [63] proposed a method for calculating the Manning coefficient using the flow velocity ratio at different depths. Much research has been done on the Manning roughness coefficient in rivers, and researchers $[49,63-66]$ sought to obtain a specific number for $n$ to use in river engineering. However, since the depth and geometric conditions of rivers are completely variable in different 
places, the values of Manning roughness coefficient have changed subsequently, and it has not been possible to choose a fixed number. In river engineering software, the Manning roughness coefficient is determined only for specific and constant conditions or normal flow. Lee et al. [63] stated that seasonal conditions, density, and type of vegetation should also be considered. Hydraulic roughness and Manning roughness coefficient $n$ of the plant were obtained by estimating the total Manning roughness coefficient from the matching of the measured water surface curve and water surface height. The following equation is used for the flow surface curve:

$$
\frac{\partial y}{\partial x}=\frac{S_{0}-S_{f}}{1-\mathrm{Fr}^{2}},
$$

where $\partial y / \partial x$ is the depth of water change, $S_{0}$ is the slope of the canal floor, $S f$ is the slope of the energy line, and Fr is the Froude number which is obtained from the following equation:

$$
F r=\frac{V}{\sqrt{g D}},
$$

where $D$ is the characteristic length of the canal. Flood flow velocity is one of the important parameters of flood waves, which is very important in calculating the water level profile and energy consumption. In the cases where there are many limitations for researchers due to the wide range of experimental dimensions and the variety of design parameters, the use of numerical methods that are able to estimate the rest of the unknown results with acceptable accuracy is economically justified.

FLOW-3D software uses Finite Difference Method (FDM) for numerical solution of two-dimensional and three-dimensional flow. This software is dedicated to computational fluid dynamics (CFD) and is provided by Flow Science [67]. The flow is divided into networks with tubular cells. For each cell there are values of dependent variables and all variables are calculated in the center of the cell, except for the velocity, which is calculated at the center of the cell. In this software, two numerical techniques have been used for geometric simulation, FAVOR ${ }^{\mathrm{TM}}$ (FractionalArea-Volume-Obstacle-Representation) and the VOF (Volume-of-Fluid) method. The equations used at this model for this research include the principle of mass survival and the magnitude of motion as follows. The fluid motion equations in three dimensions, including the Navier-Stokes equations with some additional terms, are as follows:

$$
\begin{aligned}
& \frac{\partial u}{\partial t}+\frac{1}{V_{F}}\left[u A_{x} \frac{\partial u}{\partial x}+v A_{y} R \frac{\partial u}{\partial y}+w A_{z} \frac{\partial u}{\partial z}\right]-\xi \frac{A_{y} v^{2}}{x V_{F}}=-\frac{1}{\rho} \frac{\partial P}{\partial x}+G_{x}+f_{x}-\frac{\mathrm{RSOR}}{\rho V_{F}} u \\
& \frac{\partial v}{\partial t}+\frac{1}{V_{F}}\left[u A_{x} \frac{\partial v}{\partial x}+v A_{y} R \frac{\partial v}{\partial y}+w A_{z} \frac{\partial v}{\partial z}\right]-\xi \frac{A_{y} v u}{x V_{F}}=-\frac{1}{\rho}\left(R \frac{\partial P}{\partial y}\right)+G_{y}+f_{y}-\frac{\mathrm{RSOR}}{\rho V_{F}} v \\
& \frac{\partial w}{\partial t}+\frac{1}{V_{F}}\left[u A_{x} \frac{\partial w}{\partial x}+v A_{y} R \frac{\partial w}{\partial y}+w A_{z} \frac{\partial w}{\partial z}\right]=-\frac{1}{\rho} \frac{\partial P}{\partial z}+G_{z}+f_{z}-\frac{\mathrm{RSOR}}{\rho V_{F}} w
\end{aligned}
$$

where $G_{x}, G_{y}, G_{Z}$ are mass accelerations in the directions $x$, $y, z$ and $f_{x}, f_{y}, f_{z}$ are viscosity accelerations in the directions $x, y, z$ and are obtained from the following equations:

$$
\begin{aligned}
& \rho V_{F} f_{x}=w s x-\left[\frac{\partial}{\partial x}\left(A_{x} \tau_{x x}\right)+R \frac{\partial}{\partial y}\left(A_{y} \tau_{x y}\right)+\frac{\partial}{\partial z}\left(A_{z} \tau_{x z}\right)+\frac{\xi}{x}\left(A_{x} \tau_{x x}-A_{y} \tau_{y y}\right)\right], \\
& \rho V_{F} f_{y}=w s y-\left[\frac{\partial}{\partial x}\left(A_{x} \tau_{x y}\right)+R \frac{\partial}{\partial y}\left(A_{y} \tau_{y y}\right)+\frac{\partial}{\partial z}\left(A_{z} \tau_{y z}\right)+\frac{\xi}{x}\left(A_{x}-A_{y} \tau_{x y}\right)\right], \\
& \rho V_{F} f_{z}=w s z-\left[\frac{\partial}{\partial x}\left(A_{x} \tau_{x z}\right)+R \frac{\partial}{\partial y}\left(A_{y} \tau_{y z}\right)+\frac{\partial}{\partial z}\left(A_{z} \tau_{z z}\right)+\frac{\xi}{x}\left(A_{x} \tau_{x z}\right)\right] .
\end{aligned}
$$

Shear stresses $\tau_{x x}, \tau_{y y}, \tau_{z z}, \tau_{x y}, \tau_{x z}, \tau_{y z}$ in equation (11) are obtained from the following equations: 


$$
\begin{aligned}
& \tau_{x x}=-2 \mu\left[\frac{\partial u}{\partial x}-\frac{1}{3}\left(\frac{\partial u}{\partial x}+R \frac{\partial v}{\partial y}+\frac{\partial w}{\partial z}+\frac{\xi u}{x}\right)\right], \\
& \tau_{y y}=-2 \mu\left[\frac{\partial v}{\partial y}+\xi \frac{u}{x}-\frac{1}{3}\left(\frac{\partial u}{\partial x}+R \frac{\partial v}{\partial y}+\frac{\partial w}{\partial z}+\frac{\xi u}{x}\right)\right], \\
& \tau_{z z}=-2 \mu\left[\frac{\partial w}{\partial z}-\frac{1}{3}\left(\frac{\partial u}{\partial x}+R \frac{\partial v}{\partial y}+\frac{\partial w}{\partial z}+\frac{\xi u}{x}\right)\right], \\
& \tau_{x y}=-\mu\left[\frac{\partial v}{\partial x}+R \frac{\partial u}{\partial y}-\frac{\xi v}{x}\right] \\
& \tau_{x z}=-\mu\left[\frac{\partial u}{\partial z}+\frac{\partial w}{\partial x}\right] \\
& \tau_{y z}=-\mu\left[\frac{\partial v}{\partial z}+R \frac{\partial w}{\partial y}\right] .
\end{aligned}
$$

The standard model is used for high Reynolds currents, but in this model, RNG theory allows the analytical differential formula to be used for the effective viscosity that occurs at low Reynolds numbers. Therefore, the RNG model can be used for low and high Reynolds currents.

Weather changes are high and this affects many factors continuously. The presence of vegetation in any area reduces the velocity of surface flows and prevents soil erosion, so vegetation will have a significant impact on reducing destructive floods. One of the methods of erosion protection in floodplain watersheds is the use of biological methods. The presence of vegetation in watersheds reduces the flow rate during floods and prevents soil erosion. The external organs of plants increase the roughness and decrease the velocity of water flow and thus reduce its shear stress energy. One of the important factors with which the hydraulic resistance of plants is expressed is the roughness coefficient. Measuring the roughness coefficient of plants and investigating their effect on reducing velocity and shear stress of flow is of special importance.

Roughness coefficients in canals are affected by two main factors, namely, flow conditions and vegetation characteristics [68]. So far, much research has been done on the effect of the roughness factor created by vegetation, but the issue of plant density has received less attention. For this purpose, this study was conducted to investigate the effect of vegetation density on flow velocity changes.

In a study conducted using a software model on three density modes in the submerged state effect on flow velocity changes in 48 different modes was investigated (Table 1).

The number of cells used in this simulation is equal to 1955888 cells. The boundary conditions were introduced to the model as a constant speed and depth (Figure 1). At the output boundary, due to the presence of supercritical current, no parameter for the current is considered. Absolute roughness for floors and walls was introduced to the model (Figure 1). In this case, the flow was assumed to be nonviscous and air entry into the flow was not considered. After $7.7 \times 10^{-4}$ seconds, this model reached a convergence accuracy of $2.39 \times 10^{-5}$.

Due to the fact that it is not possible to model the vegetation in FLOW-3D software, in this research, the vegetation of small soft plants was studied so that Manning's coefficients can be entered into the canal bed in the form of roughness coefficients obtained from the studies of Chow [69] in similar conditions. In practice, in such modeling, the effect of plant height is eliminated due to the small height of herbaceous plants, and modeling can provide relatively acceptable results in these conditions.

48 models with input velocities proportional to the height of the regular semihexagonal canal were considered to create supercritical conditions. Manning coefficients were applied based on Chow [69] studies in order to control the canal bed. Speed profiles were drawn and discussed.

Any control and simulation system has some inputs that we should determine to test any technology [70-77]. Determination and true implementation of such parameters is one of the key steps of any simulation [23, 78-81] and computing procedure [82-86]. The input current is created by applying the flow rate through the VFR (Volume Flow Rate) option and the output flow is considered Output and for other borders the Symmetry option is considered.

Simulation of the models and checking their action and responses and observing how a process behaves is one of the accepted methods in engineering and science [87, 88]. For verification of FLOW-3D software, the results of computer simulations are compared with laboratory measurements and according to the values of computational error, convergence error, and the time required for convergence, the most appropriate option for real-time simulation is selected (Figures 2 and 3 ).

The canal is 7 meters long, 0.5 meters wide, and 0.8 meters deep. This test was used to validate the application of the software to predict the flow rate parameters. In this experiment, instead of using the plant, cylindrical pipes were used in the bottom of the canal.

The conditions of this modeling are similar to the laboratory conditions and the boundary conditions used in the laboratory were used for numerical modeling. The critical flow enters the simulation model from the upstream boundary, so in the upstream boundary conditions, critical velocity and depth are considered. The flow at the downstream boundary is supercritical, so no parameters are applied to the downstream boundary.

The software well predicts the process of changing the speed profile in the open canal along with the considered obstacles. The error in the calculated speed values can be due to the complexity of the flow and the interaction of the turbulence caused by the roughness of the floor with the 
TABLE 1: The studied models.

\begin{tabular}{|c|c|c|c|c|c|c|c|c|}
\hline Model index & Study models & $\mathrm{Z}$ & G & $\begin{array}{l}\text { Hydraulic } \\
\text { depth }\end{array}$ & $\begin{array}{l}\text { Input } \\
\text { speed }\end{array}$ & $\begin{array}{l}\text { Froude } \\
\text { number }\end{array}$ & $\begin{array}{l}\text { Plant } \\
\text { density }\end{array}$ & $\begin{array}{l}\text { Manning coefficient based on Chow's } \\
\text { experiences }\end{array}$ \\
\hline Model1-V3-Ch 0.03 & Model 1 & 1 & 9.81 & 0.88 & 3 & 1.016409 & 0.25 & 0.03 \\
\hline Model2-V3-Ch 0.035 & Model 2 & 1 & 9.81 & 0.88 & 3 & 1.016409 & 0.5 & 0.035 \\
\hline Model3-V3-Ch 0.04 & Model 3 & 1 & 9.81 & 0.88 & 3 & 1.016409 & 0.75 & 0.04 \\
\hline Model4-V3-Ch 0.02 & Model 4 & 1 & 9.81 & 0.88 & 3 & 1.016409 & 0 & 0.02 \\
\hline Model5-V3.1-Ch 0.03 & Model 5 & 1 & 9.81 & 0.88 & 3.1 & 1.0502893 & 0.25 & 0.03 \\
\hline Model6-V3.1-Ch 0.035 & Model 6 & 1 & 9.81 & 0.88 & 3.1 & 1.0502893 & 0.5 & 0.035 \\
\hline Model7-V3.1-Ch 0.04 & Model 7 & 1 & 9.81 & 0.88 & 3.1 & 1.0502893 & 0.75 & 0.04 \\
\hline Model8-V3.1-Ch 0.02 & Model 8 & 1 & 9.81 & 0.88 & 3.1 & 1.0502893 & 0 & 0.02 \\
\hline Model9-V3.2-Ch 0.03 & Model 9 & 1 & 9.81 & 0.88 & 3.2 & 1.0841696 & 0.25 & 0.03 \\
\hline $\begin{array}{l}\text { Model10-V3.2-Ch } \\
0.035\end{array}$ & Model 10 & 1 & 9.81 & 0.88 & 3.2 & 1.0841696 & 0.5 & 0.035 \\
\hline Model11-V3.2-Ch 0.04 & Model 11 & 1 & 9.81 & 0.88 & 3.2 & 1.0841696 & 0.75 & 0.04 \\
\hline Model12-V3.2-Ch 0.02 & Model 12 & 1 & 9.81 & 0.88 & 3.2 & 1.0841696 & 0 & 0.02 \\
\hline Model13-V3.3-Ch 0.03 & Model 13 & 1 & 9.81 & 0.88 & 3.3 & 1.1180499 & 0.25 & 0.03 \\
\hline $\begin{array}{l}\text { Model14-V3.3-Ch } \\
0.035\end{array}$ & Model 14 & 1 & 9.81 & 0.88 & 3.3 & 1.1180499 & 0.5 & 0.035 \\
\hline Model15-V3.3-Ch 0.04 & Model 15 & 1 & 9.81 & 0.88 & 3.3 & 1.1180499 & 0.75 & 0.04 \\
\hline Model16-V3.3-Ch 0.02 & Model 16 & 1 & 9.81 & 0.88 & 3.3 & 1.1180499 & 0 & 0.02 \\
\hline Model17-V4-Ch 0.03 & Model 17 & 2 & 9.81 & 1.46 & 4 & 1.055455338 & 0.25 & 0.03 \\
\hline Model18-V4-Ch 0.035 & Model 18 & 2 & 9.81 & 1.46 & 4 & 1.055455338 & 0.5 & 0.035 \\
\hline Model19-V4-Ch 0.04 & Model 19 & 2 & 9.81 & 1.46 & 4 & 1.055455338 & 0.75 & 0.04 \\
\hline Model20-V4-Ch 0.02 & Model 20 & 2 & 9.81 & 1.46 & 4 & 1.055455338 & 0 & 0.02 \\
\hline Model21-V4.1-Ch 0.03 & Model 21 & 2 & 9.81 & 1.46 & 4.1 & 1.081841721 & 0.25 & 0.03 \\
\hline Model22-V4.1-Ch 0.035 & Model 22 & 2 & 9.81 & 1.46 & 4.1 & 1.081841721 & 0.5 & 0.035 \\
\hline Model23-V4.1-Ch 0.04 & Model 23 & 2 & 9.81 & 1.46 & 4.1 & 1.081841721 & 0.75 & 0.04 \\
\hline Model24-V4.1-Ch 0.02 & Model 24 & 2 & 9.81 & 1.46 & 4.1 & 1.081841721 & 0 & 0.02 \\
\hline Model25-V4.2-Ch 0.03 & Model 25 & 2 & 9.81 & 1.46 & 4.2 & 1.108228105 & 0.25 & 0.03 \\
\hline $\begin{array}{l}\text { Model26-V4.2-Ch } \\
0.035\end{array}$ & Model 26 & 2 & 9.81 & 1.46 & 4.2 & 1.108228105 & 0.5 & 0.035 \\
\hline Model27-V4.2-Ch 0.04 & Model 27 & 2 & 9.81 & 1.46 & 4.2 & 1.108228105 & 0.75 & 0.04 \\
\hline Model28-V4.2-Ch 0.02 & Model 28 & 2 & 9.81 & 1.46 & 4.2 & 1.108228105 & 0 & 0.02 \\
\hline Model29-V4.3-Ch 0.03 & Model 29 & 2 & 9.81 & 1.46 & 4.3 & 1.134614488 & 0.25 & 0.03 \\
\hline $\begin{array}{l}\text { Model30-V4.3-Ch } \\
0.035\end{array}$ & Model 30 & 2 & 9.81 & 1.46 & 4.3 & 1.134614488 & 0.5 & 0.035 \\
\hline Model31-V4.3-Ch 0.04 & Model 31 & 2 & 9.81 & 1.46 & 4.3 & 1.134614488 & 0.75 & 0.04 \\
\hline Model32-V4.3-Ch 0.02 & Model 32 & 2 & 9.81 & 1.46 & 4.3 & 1.134614488 & 0 & 0.02 \\
\hline Model33-V5-Ch 0.03 & Model 33 & 3 & 9.81 & 1.91 & 5 & 1.153022908 & 0.25 & 0.03 \\
\hline Model34-V5-Ch 0.035 & Model 34 & 3 & 9.81 & 1.91 & 5 & 1.153022908 & 0.5 & 0.035 \\
\hline Model35-V5-Ch 0.04 & Model 35 & 3 & 9.81 & 1.91 & 5 & 1.153022908 & 0.75 & 0.04 \\
\hline Model36-V5-Ch 0.02 & Model 36 & 3 & 9.81 & 1.91 & 5 & 1.153022908 & 0 & 0.02 \\
\hline Model37-V5.1-Ch 0.03 & Model 37 & 3 & 9.81 & 1.91 & 5.1 & 1.176083366 & 0.25 & 0.03 \\
\hline Model38-V5.1-Ch 0.035 & Model 38 & 3 & 9.81 & 1.91 & 5.1 & 1.176083366 & 0.5 & 0.035 \\
\hline Model39-V5.1-Ch 0.04 & Model 39 & 3 & 9.81 & 1.91 & 5.1 & 1.176083366 & 0.75 & 0.04 \\
\hline Model40-V5.1-Ch 0.02 & Model 40 & 3 & 9.81 & 1.91 & 5.1 & 1.176083366 & 0 & 0.02 \\
\hline Model41-V5.2-Ch 0.03 & Model 41 & 3 & 9.81 & 1.91 & 5.2 & 1.199143825 & 0.25 & 0.03 \\
\hline $\begin{array}{l}\text { Model42-V5.2-Ch } \\
0.035\end{array}$ & Model 42 & 3 & 9.81 & 1.91 & 5.2 & 1.199143825 & 0.5 & 0.035 \\
\hline Model43-V5.2-Ch 0.04 & Model 43 & 3 & 9.81 & 1.91 & 5.2 & 1.199143825 & 0.75 & 0.04 \\
\hline Model44-V5.2-Ch 0.02 & Model 44 & 3 & 9.81 & 1.91 & 5.2 & 1.199143825 & 0 & 0.02 \\
\hline Model45-V5.3-Ch 0.03 & Model 45 & 3 & 9.81 & 1.91 & 5.3 & 1.222204283 & 0.25 & 0.03 \\
\hline $\begin{array}{l}\text { Model46-V5.3-Ch } \\
0.035\end{array}$ & Model 46 & 3 & 9.81 & 1.91 & 5.3 & 1.222204283 & 0.5 & 0.035 \\
\hline Model47-V5.3-Ch 0.04 & Model 47 & 3 & 9.81 & 1.91 & 5.3 & 1.222204283 & 0.75 & 0.04 \\
\hline Model48-V5.3-Ch 0.02 & Model 48 & 3 & 9.81 & 1.91 & 5.3 & 1.222204283 & 0 & 0.02 \\
\hline
\end{tabular}




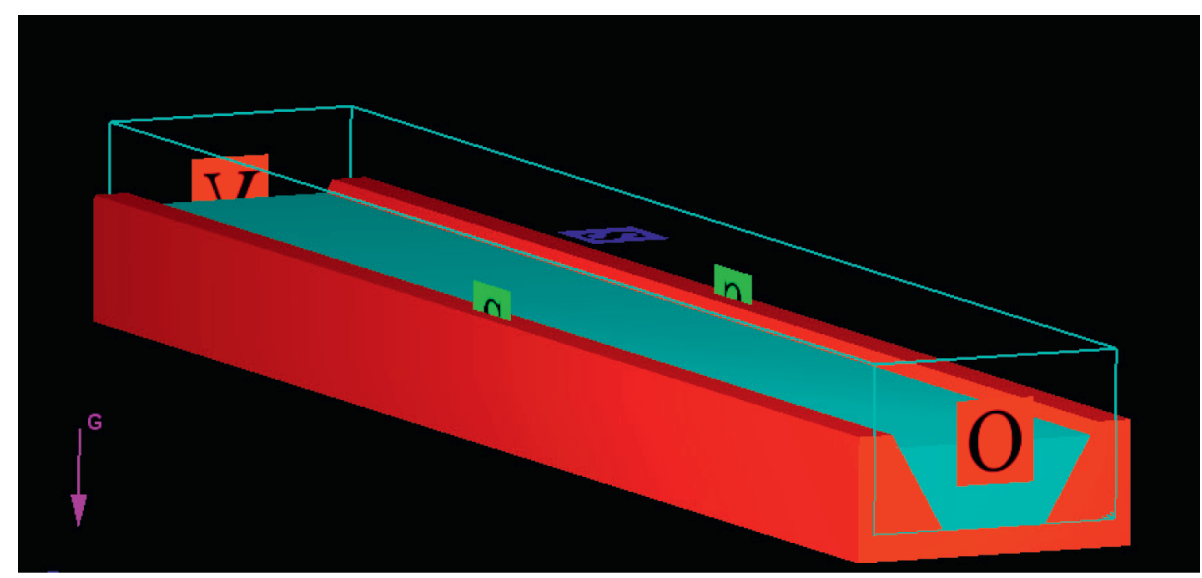

FIgURE 1: The simulated model and its boundary conditions.

turbulence caused by the three-dimensional cycles in the hydraulic jump. As a result, the software is able to predict the speed distribution in open canals.

\section{Modeling Results}

After analyzing the models, the results were shown in graphs (Figures 4-14 ). The total number of experiments in this study was 48 due to the limitations of modeling.

To investigate the effects of roughness with flow velocity, the trend of flow velocity changes at different depths and with supercritical flow to a Froude number proportional to the depth of the section has been obtained.

According to the velocity profiles of Figure 5, it can be seen that, with the increasing of Manning's coefficient, the canal bed speed decreases.

According to Figures 5 to 8 , it can be found that, with increasing the Manning's coefficient, the canal bed speed decreases. But this deceleration is more noticeable than the deceleration of the models 1 to 12, which can be justified by increasing the speed and of course increasing the Froude number.

According to Figure 10, we see that, with increasing Manning's coefficient, the canal bed speed decreases.

According to Figure 11, we see that, with increasing Manning's coefficient, the canal bed speed decreases. But this deceleration is more noticeable than the deceleration of Figures 5-10, which can be justified by increasing the speed and, of course, increasing the Froude number.

With increasing Manning's coefficient, the canal bed speed decreases (Figure 12). But this deceleration is more noticeable than the deceleration of the higher models (Figures 5-8 and 10,11), which can be justified by increasing the speed and, of course, increasing the Froude number.

According to Figure 13, with increasing Manning's coefficient, the canal bed speed decreases. But this deceleration is more noticeable than the deceleration of Figures 5 to 12 , which can be justified by increasing the speed and, of course, increasing the Froude number.

According to Figure 15, with increasing Manning's coefficient, the canal bed speed decreases.
According to Figure 16, with increasing Manning's coefficient, the canal bed speed decreases. But this deceleration is more noticeable than the deceleration of the higher model, which can be justified by increasing the speed and, of course, increasing the Froude number.

According to Figure 17, it is clear that, with increasing Manning's coefficient, the canal bed speed decreases. But this deceleration is more noticeable than the deceleration of the higher models, which can be justified by increasing the speed and, of course, increasing the Froude number.

According to Figure 18, with increasing Manning's coefficient, the canal bed speed decreases. But this deceleration is more noticeable than the deceleration of the higher models, which can be justified by increasing the speed and, of course, increasing the Froude number.

According to Figure 19, it can be seen that the vegetation placed in front of the flow input velocity has negligible effect on the reduction of velocity, which of course can be justified due to the flexibility of the vegetation. The only unusual thing is the unexpected decrease in floor speed of $3 \mathrm{~m} / \mathrm{s}$ compared to higher speeds.

According to Figure 20, by increasing the speed of vegetation, the effect of vegetation on reducing the flow rate becomes more noticeable. And the role of input current does not have much effect in reducing speed.

According to Figure 21, it can be seen that, with increasing speed, the effect of vegetation on reducing the bed flow rate becomes more noticeable and the role of the input current does not have much effect. In general, it can be seen that, by increasing the speed of the input current, the slope of the profiles increases from the bed to the water surface and due to the fact that, in software, the roughness coefficient applies to the channel floor only in the boundary conditions, this can be perfectly justified. Of course, it can be noted that, due to the flexible conditions of the vegetation of the bed, this modeling can show acceptable results for such grasses in the canal floor. In the next directions, we may try application of swarm-based optimization methods for modeling and finding the most effective factors in this research $[2,7,8,15,18,89-94]$. In future, we can also apply the 


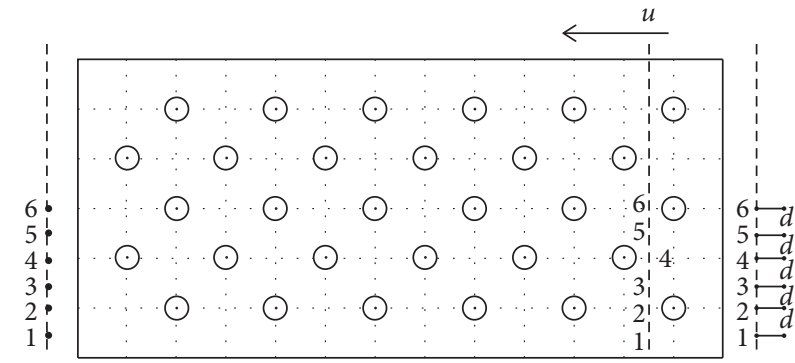

Section 3

Section 2 Section 1

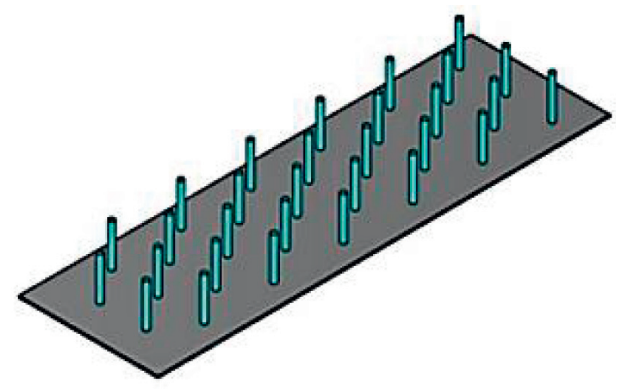

Figure 2: Modeling the plant with cylindrical tubes at the bottom of the canal.

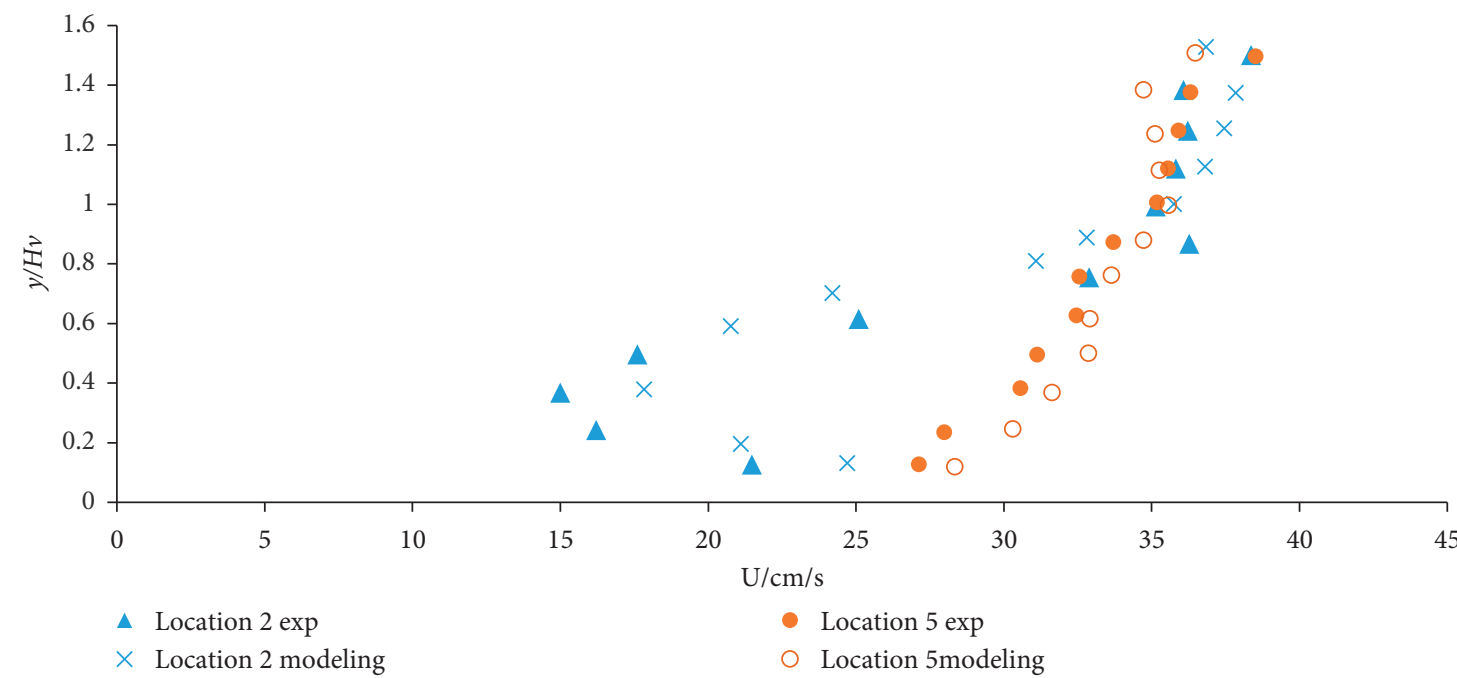

Figure 3: Velocity profiles in positions 2 and 5.

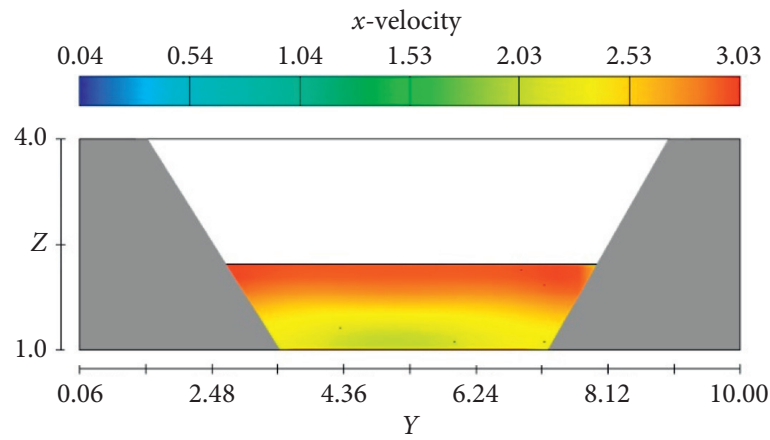

(a)

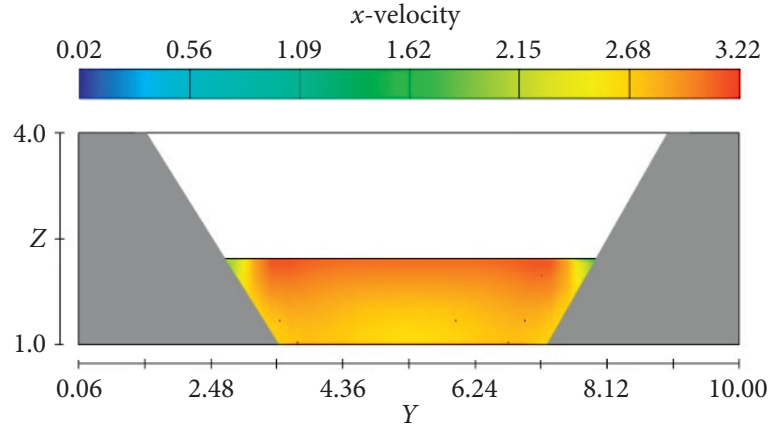

(c)

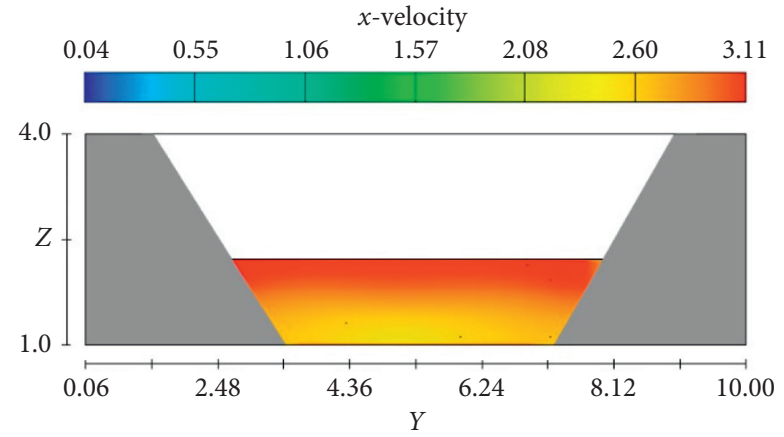

(b)

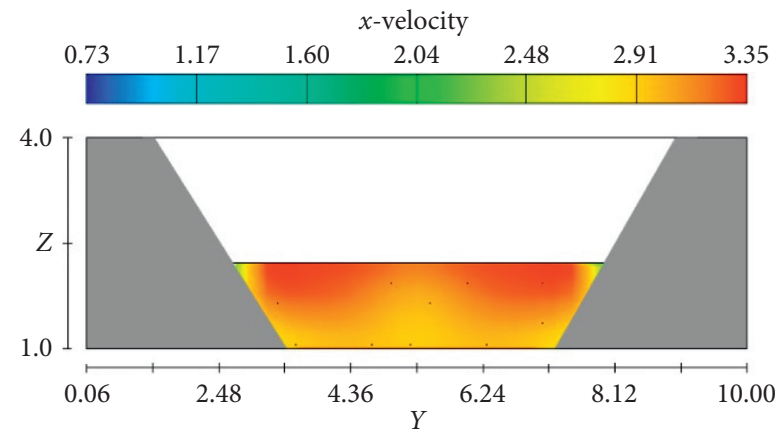

(d)

Figure 4: Flow velocity profiles for canals with a depth of $1 \mathrm{~m}$ and flow velocities of 3-3.3 m/s. Canal with a depth of $1 \mathrm{~meter}$ and a flow velocity of (a) 3 meters per second, (b) 3.1 meters per second, (c) 3.2 meters per second, and (d) 3.3 meters per second. 

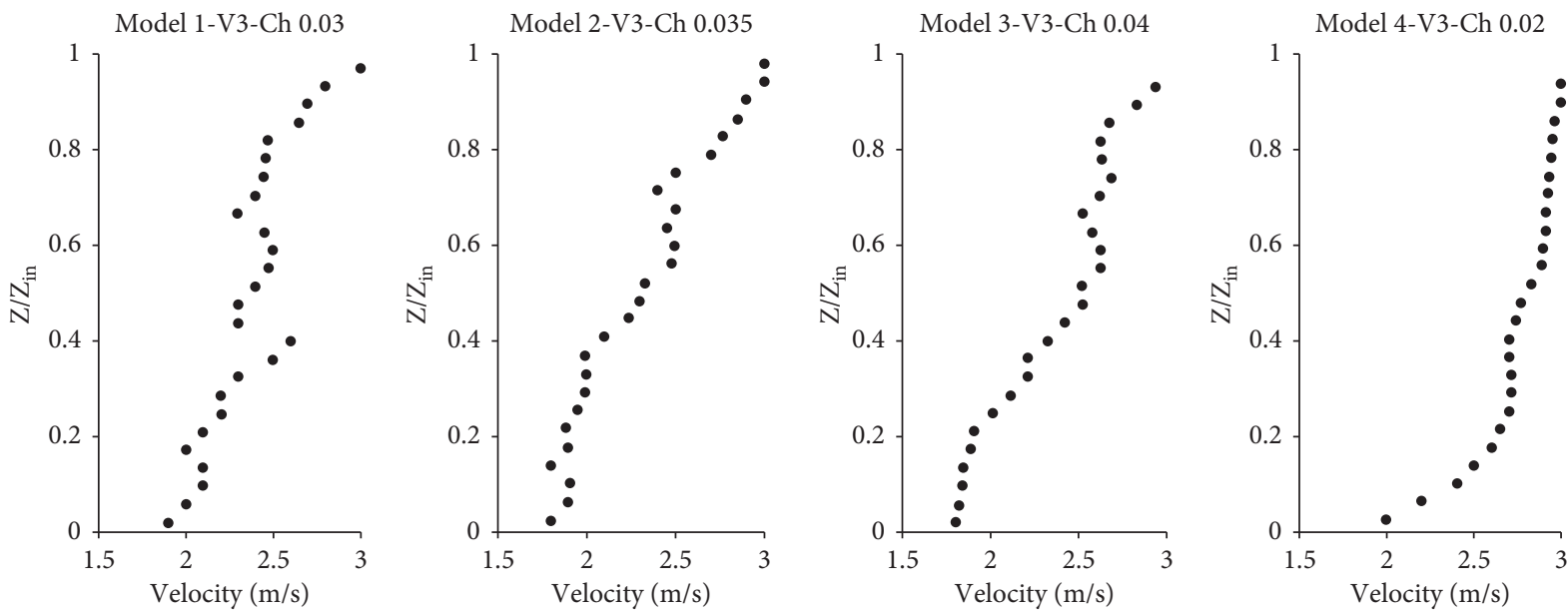

FIGURE 5: Canal diagram with a depth of 1 meter and a flow rate of 3 meters per second.
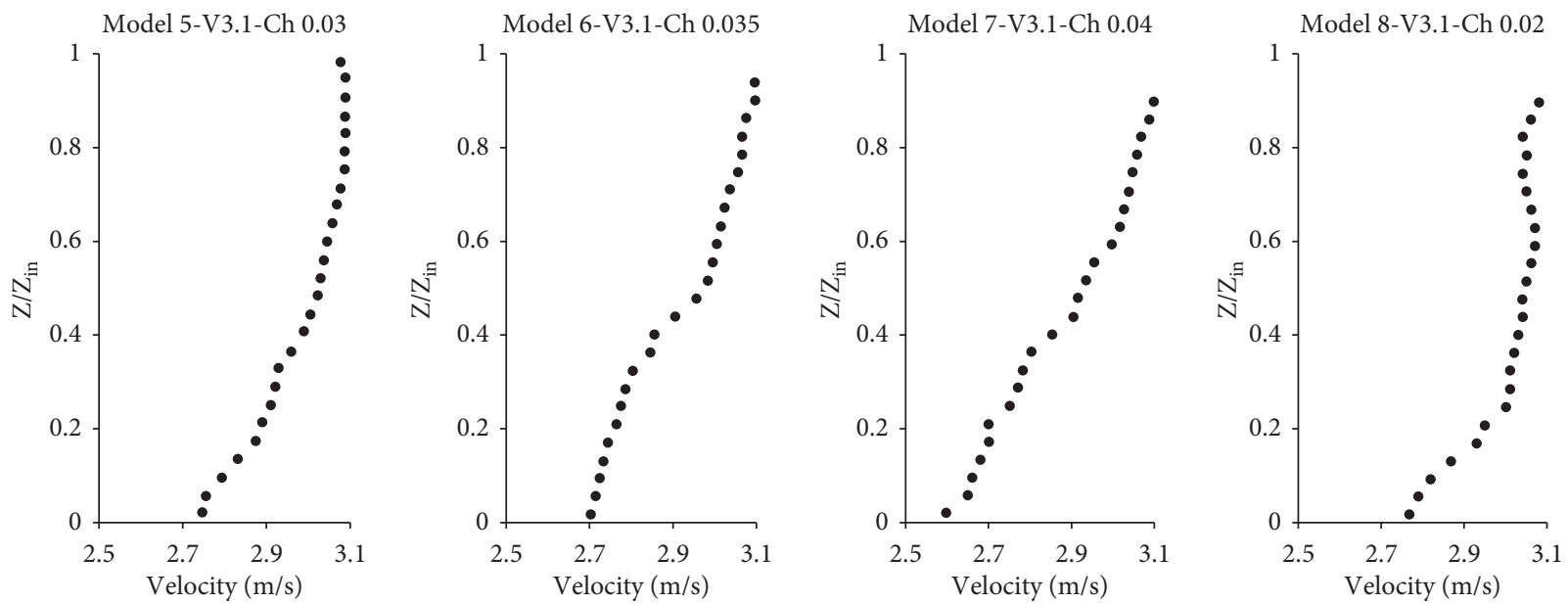

Figure 6: Canal diagram with a depth of 1 meter and a flow rate of 3.1 meters per second.
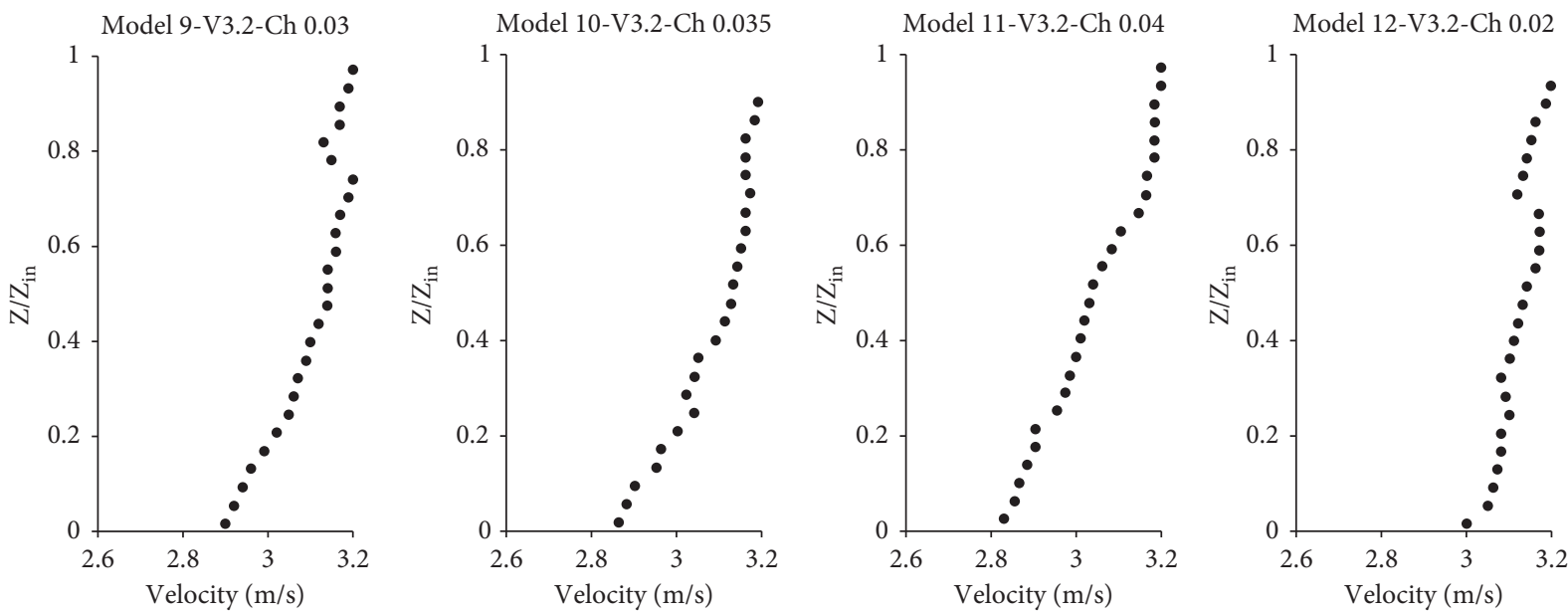

Figure 7: Canal diagram with a depth of 1 meter and a flow rate of 3.2 meters per second. 

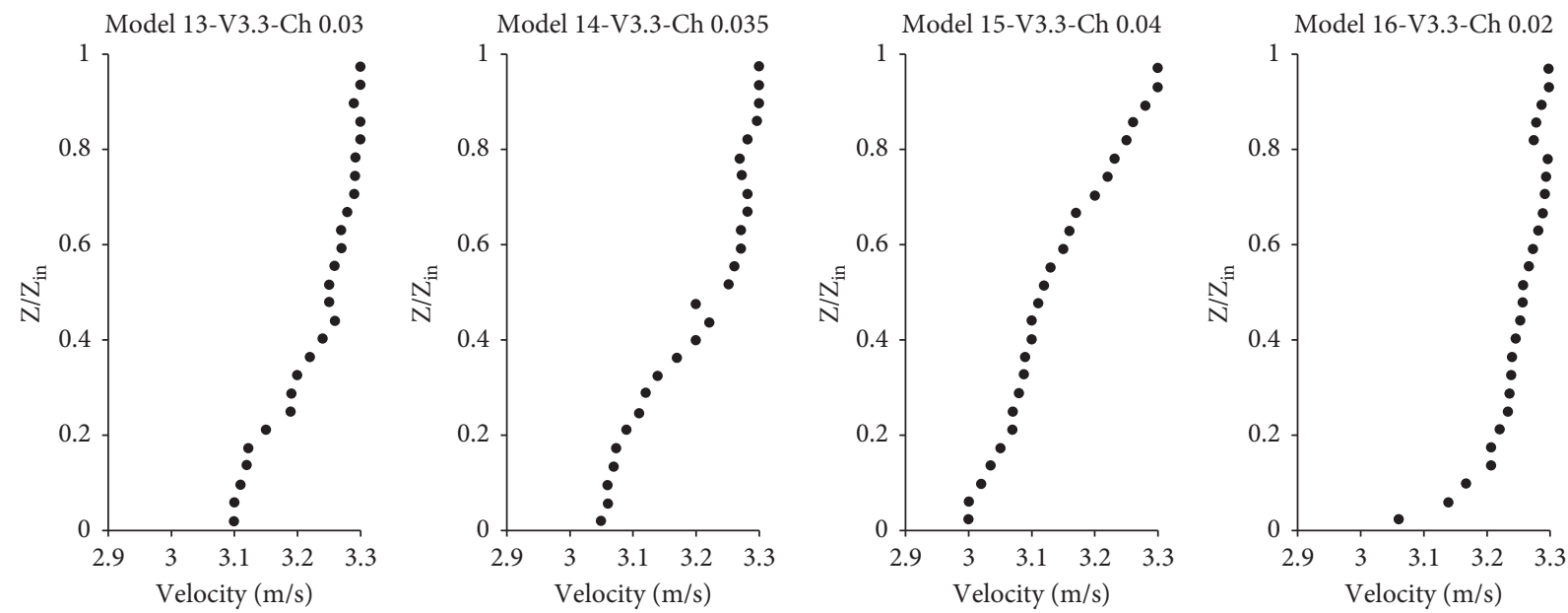

Figure 8: Canal diagram with a depth of 1 meter and a flow rate of 3.3 meters per second.

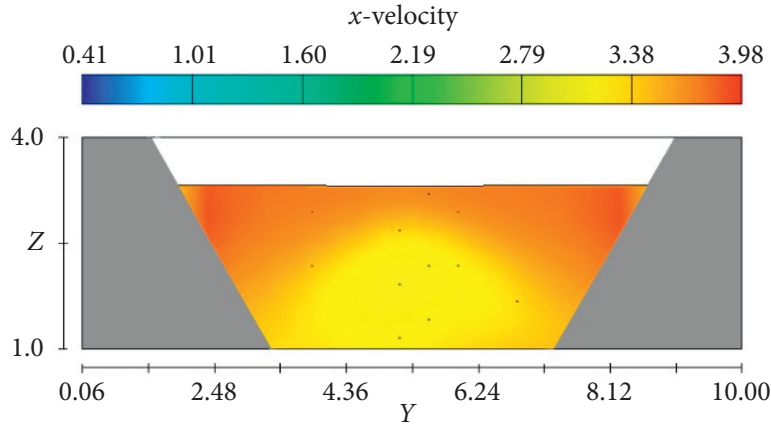

(a)

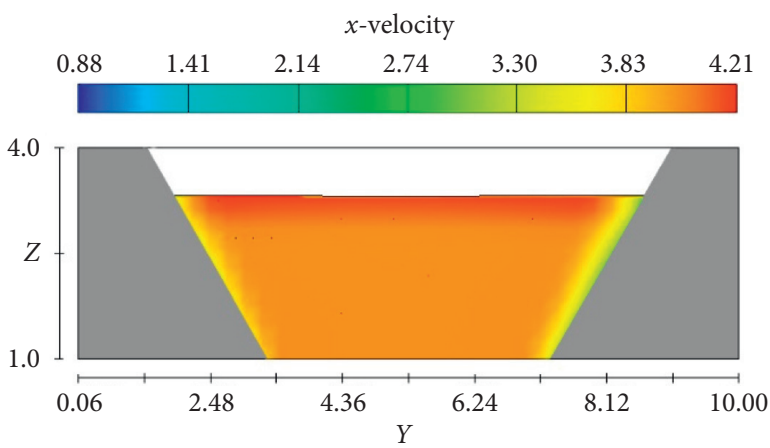

(c)

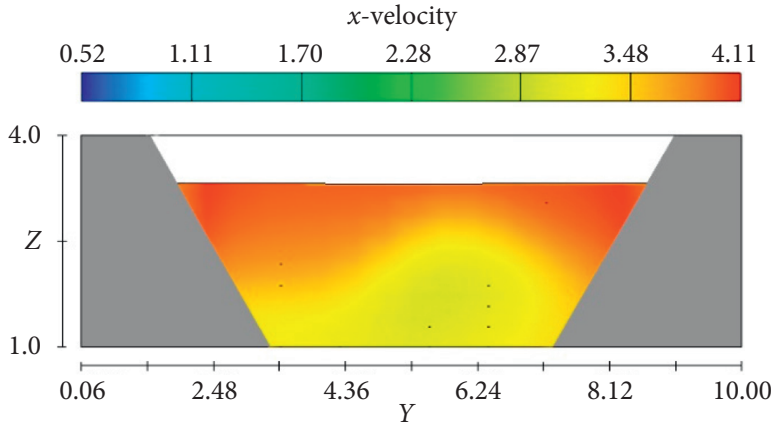

(b)

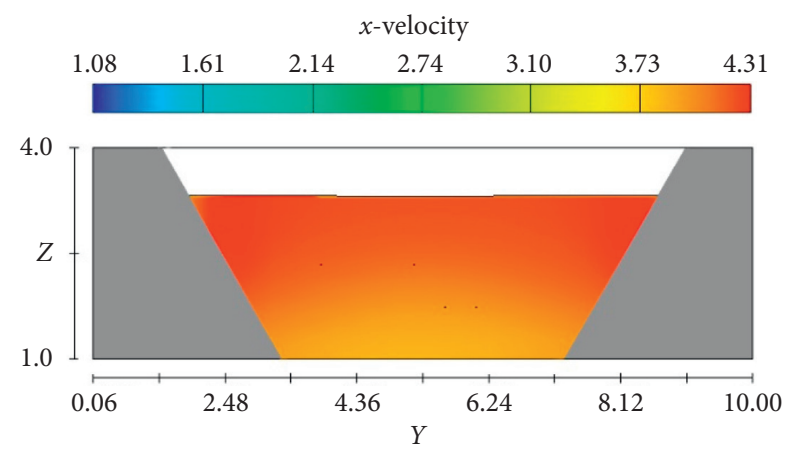

(d)

Figure 9: Flow velocity profiles for canals with a depth of $2 \mathrm{~m}$ and flow velocities of $4-4.3 \mathrm{~m} / \mathrm{s}$. Canal with a depth of 2 meters and a flow rate of (a) 4 meters per second, (b) 4.1 meters per second, (c) 4.2 meters per second, and (d) 4.3 meters per second. 

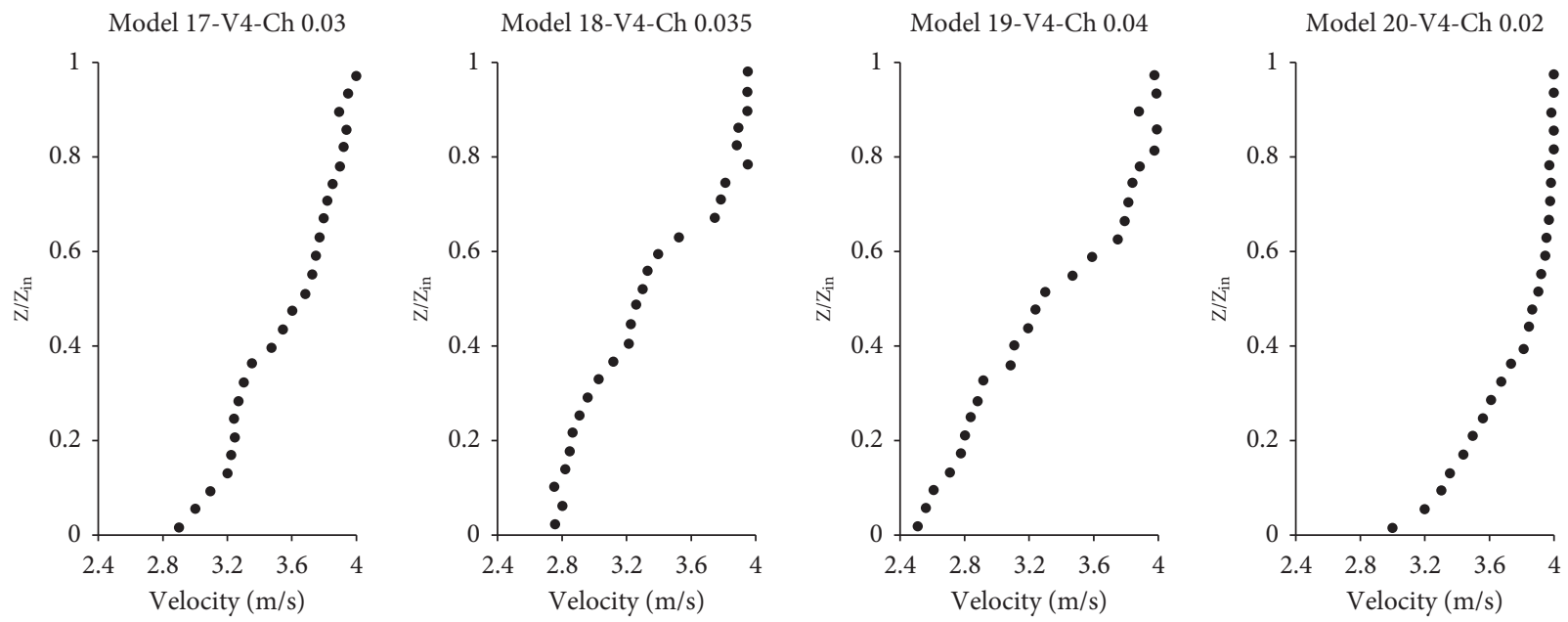

Figure 10: Canal diagram with a depth of 2 meters and a flow rate of 4 meters per second.
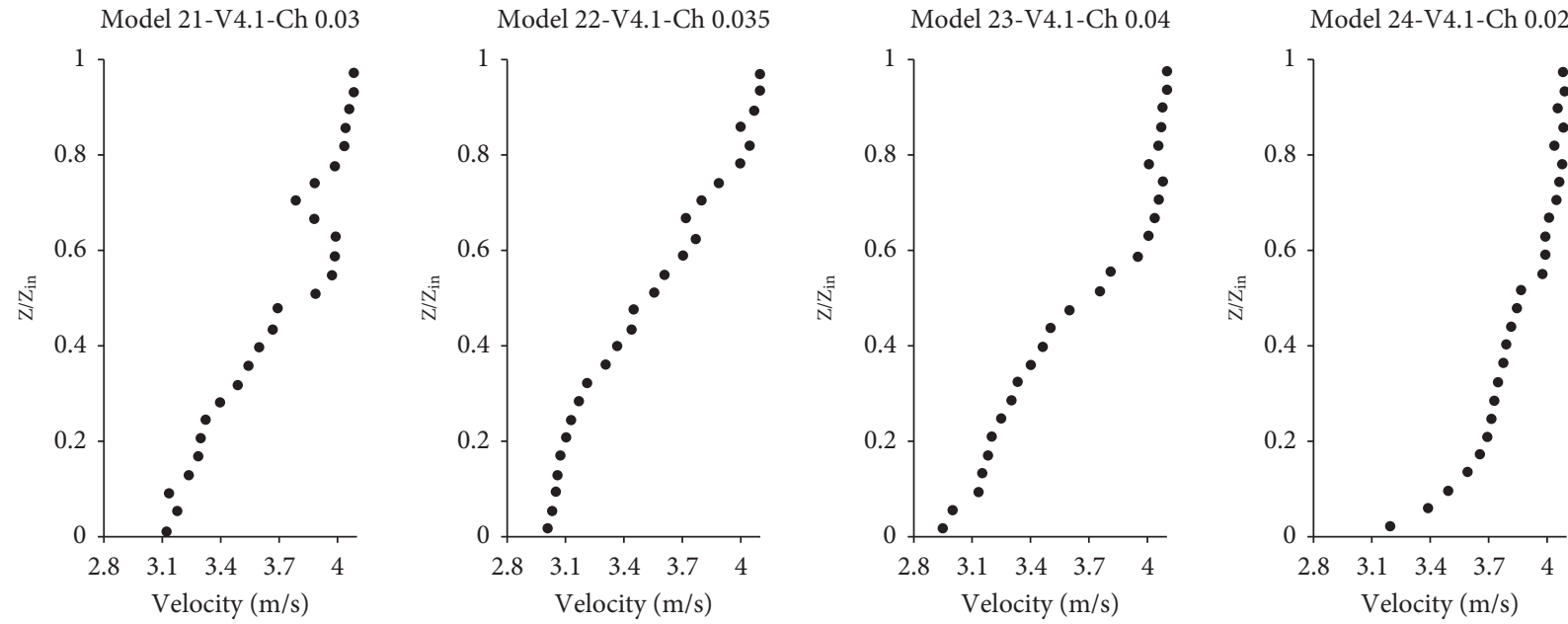

Figure 11: Canal diagram with a depth of 2 meters and a flow rate of 4.1 meters per second.
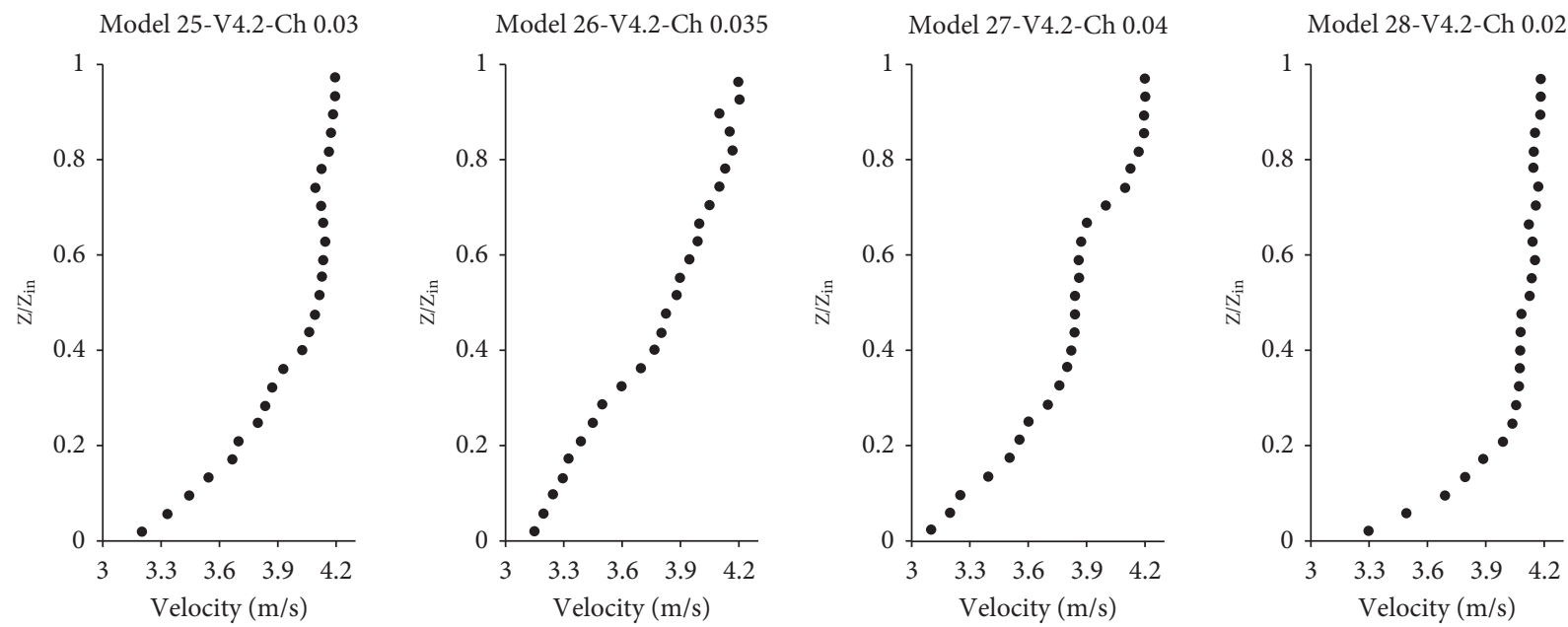

Figure 12: Canal diagram with a depth of 2 meters and a flow rate of 4.2 meters per second. 

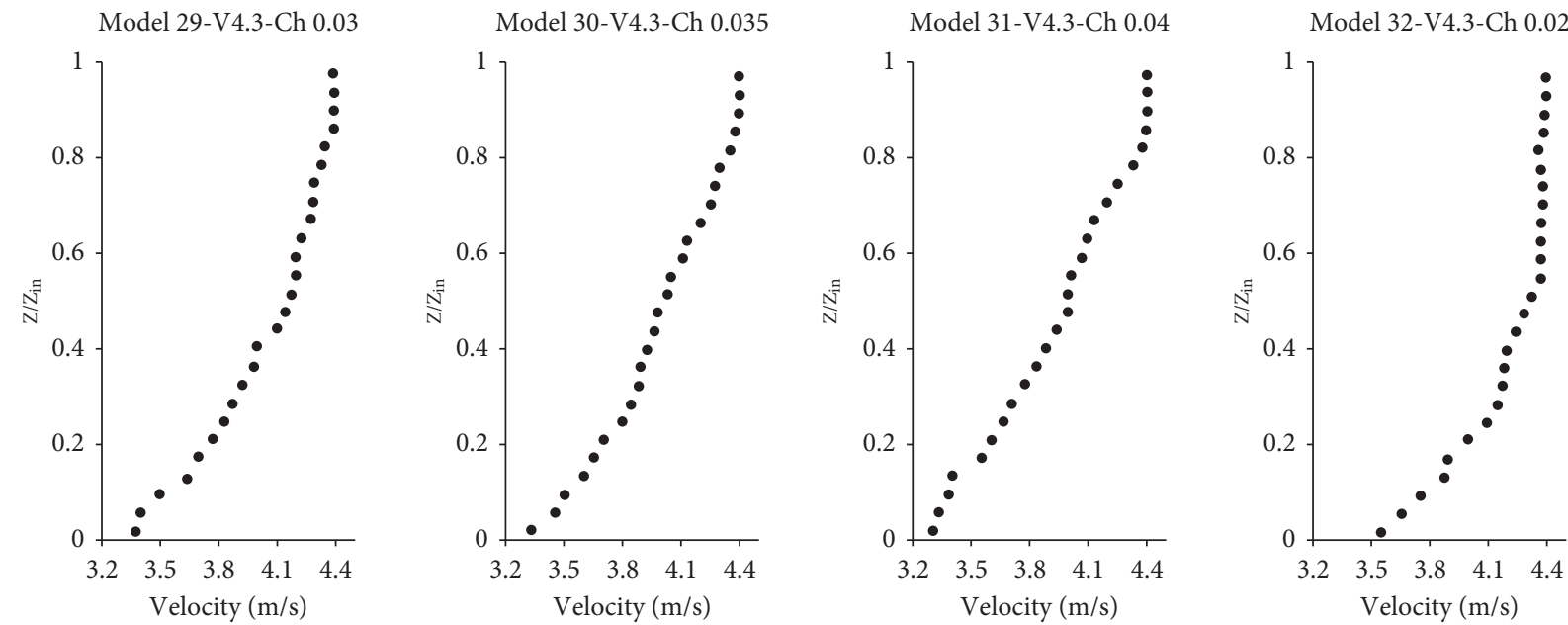

Figure 13: Canal diagram with a depth of 2 meters and a flow rate of 4.3 meters per second.

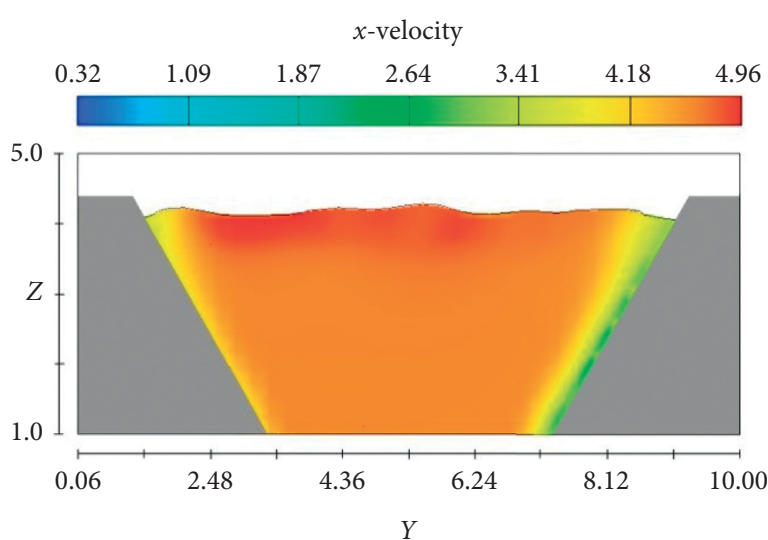

(a)

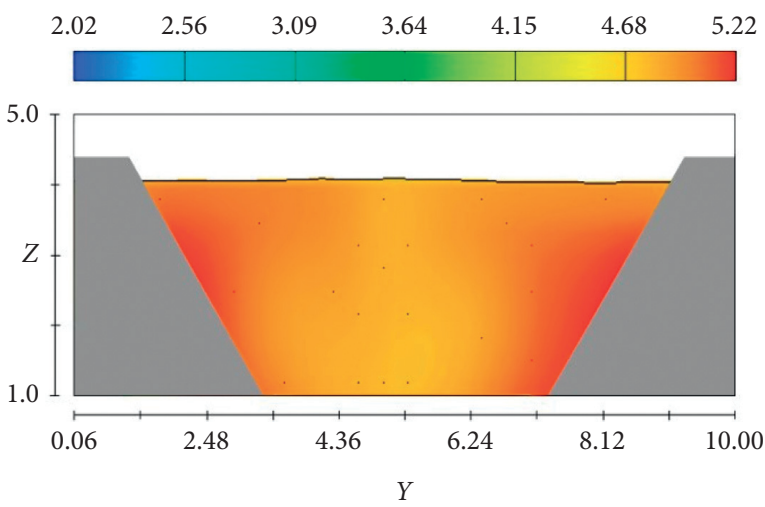

(c)

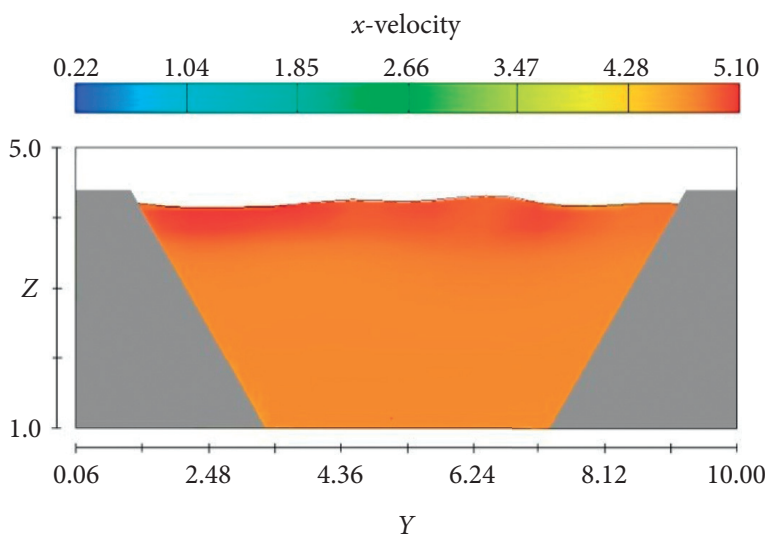

(b)

$x$-velocity

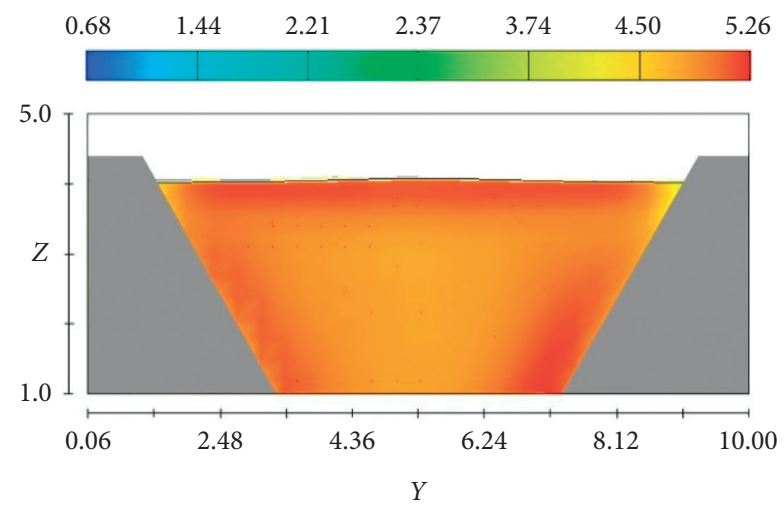

(d)

Figure 14: Flow velocity profiles for canals with a depth of $3 \mathrm{~m}$ and flow velocities of 5-5.3 m/s. Canal with a depth of 2 meters and a flow rate of (a) 4 meters per second, (b) 4.1 meters per second, (c) 4.2 meters per second, and (d) 4.3 meters per second. 

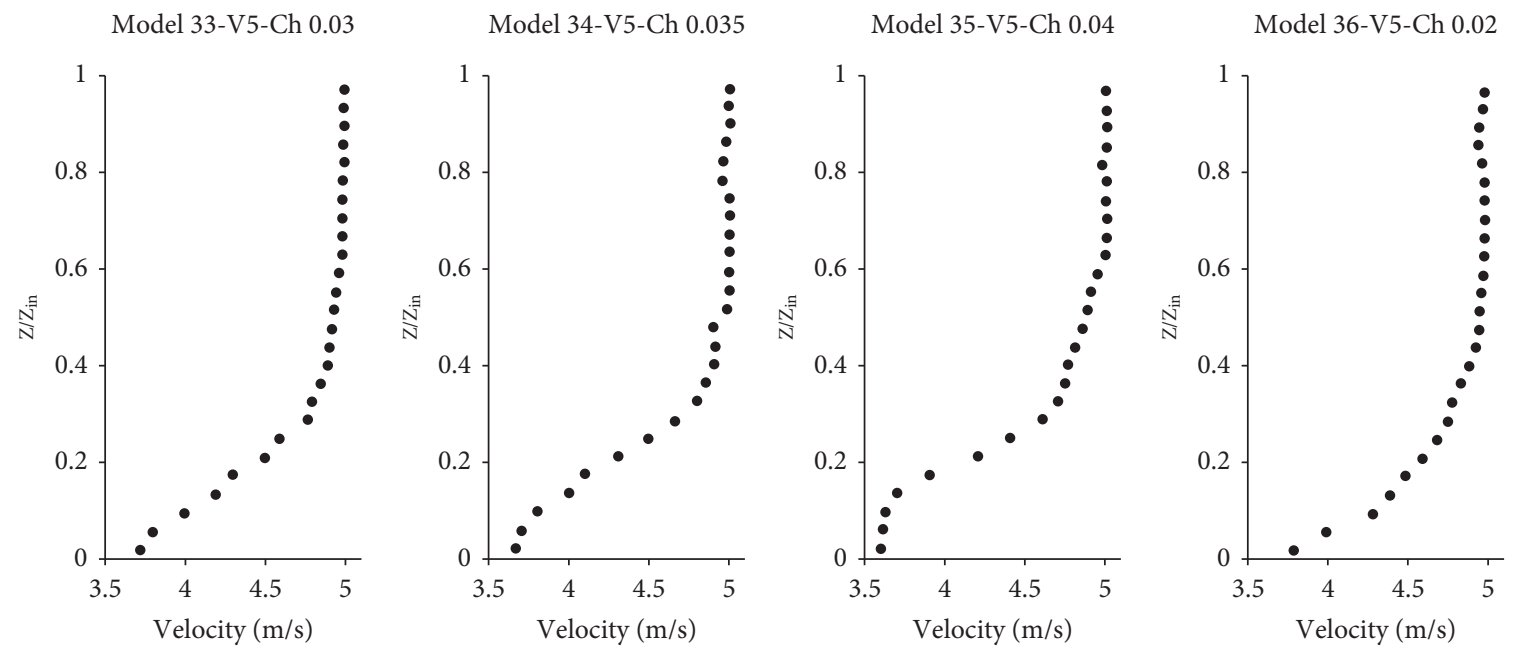

Figure 15: Canal diagram with a depth of 3 meters and a flow rate of 5 meters per second.
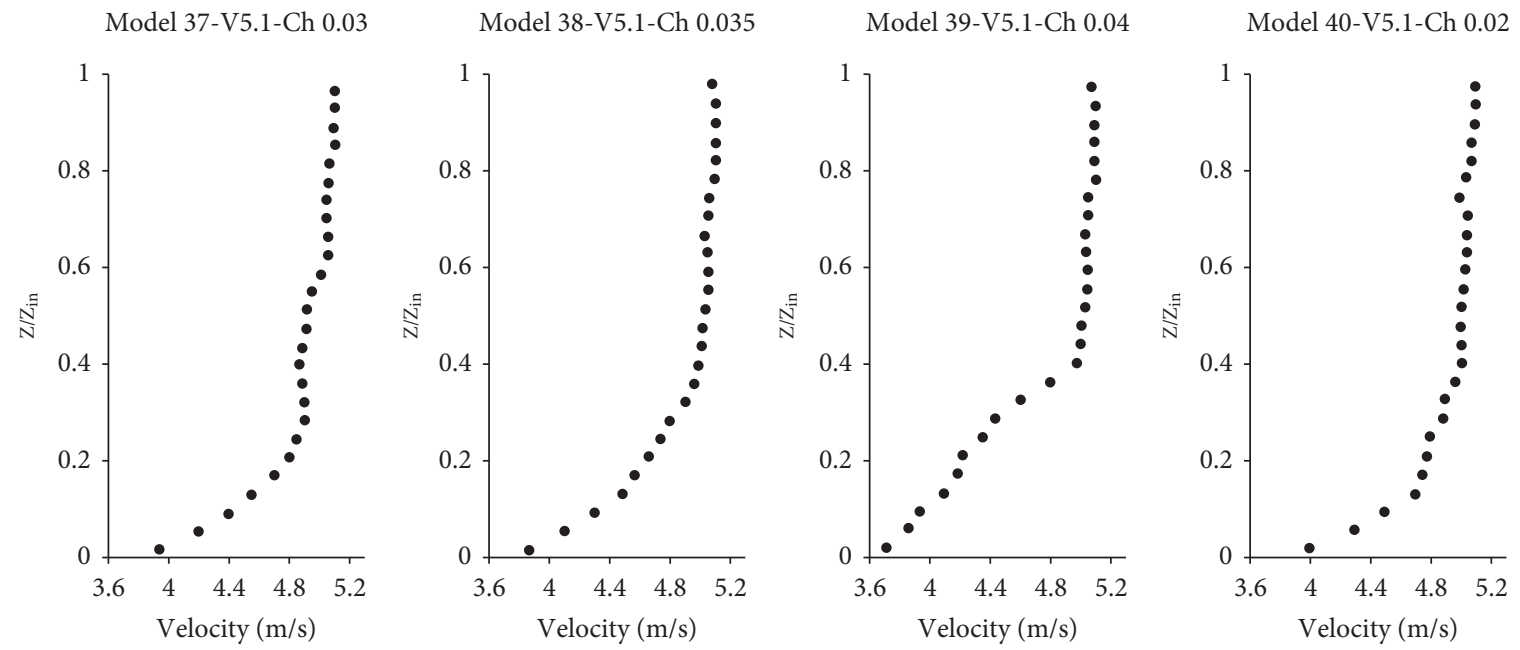

Figure 16: Canal diagram with a depth of 3 meters and a flow rate of 5.1 meters per second.
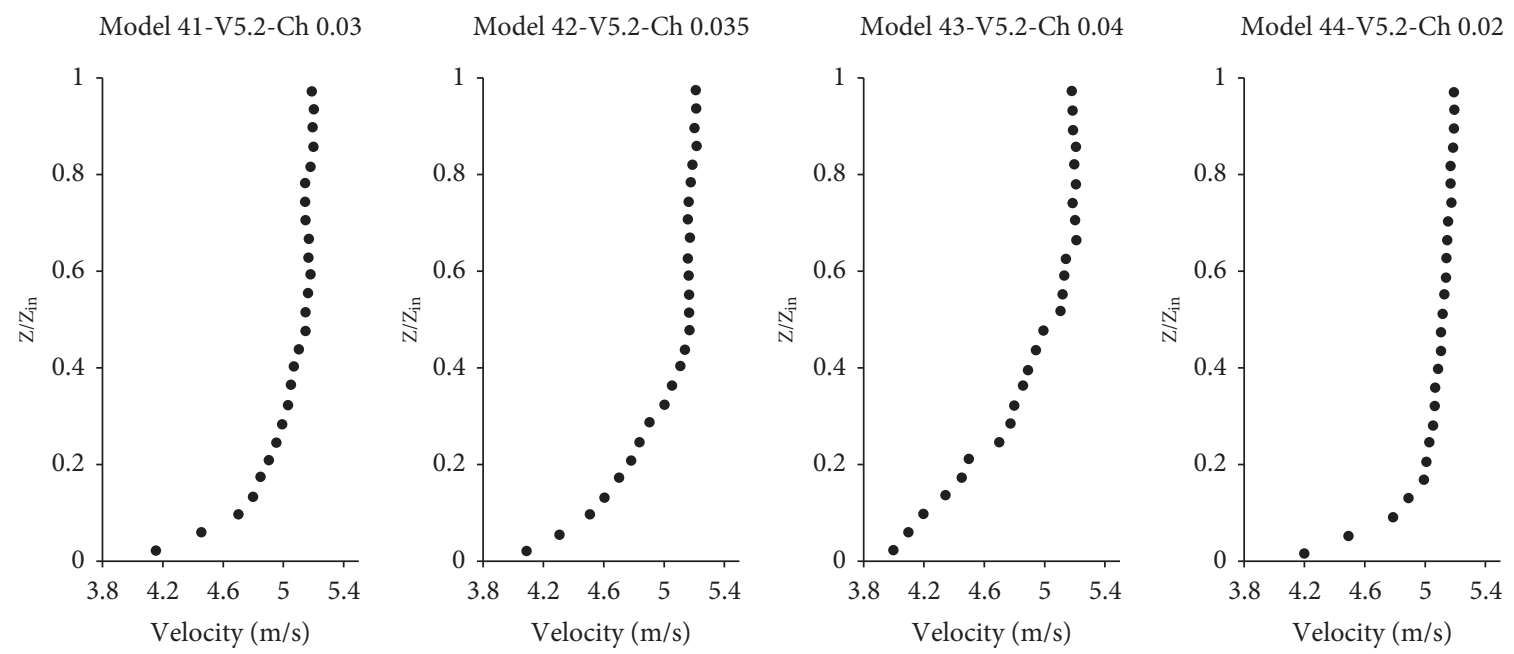

Figure 17: Canal diagram with a depth of 3 meters and a flow rate of 5.2 meters per second. 

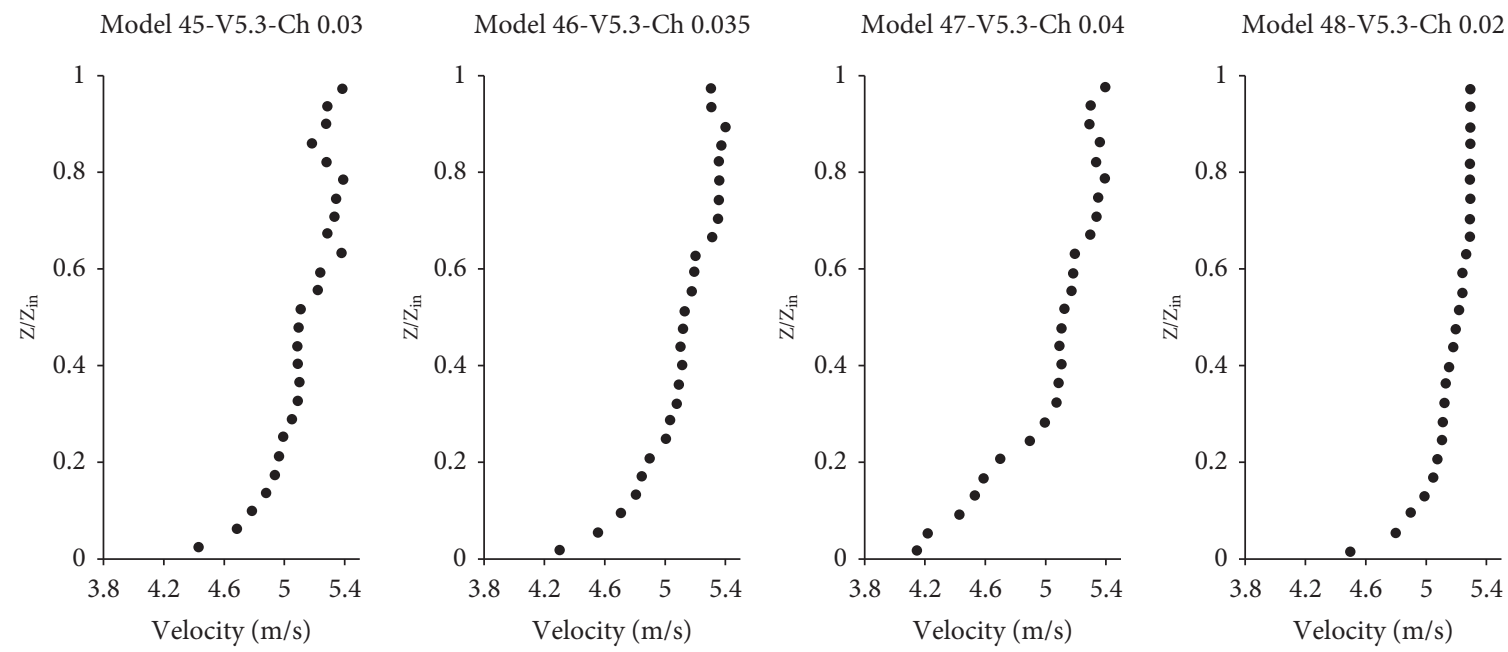

Figure 18: Canal diagram with a depth of 3 meters and a flow rate of 5.3 meters per second.

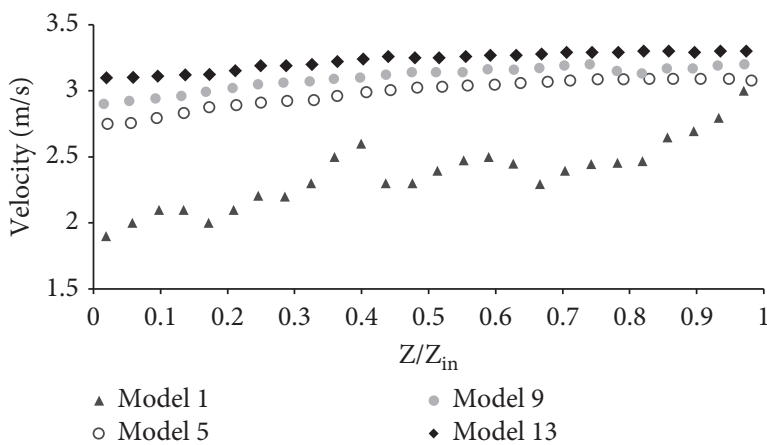

(a)

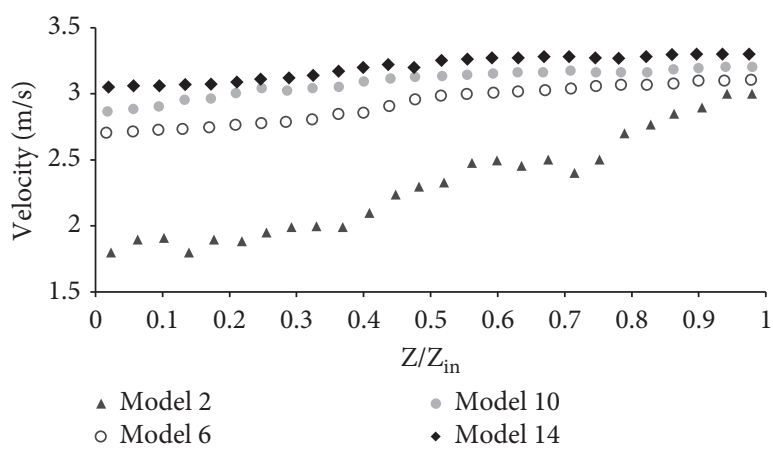

(b)

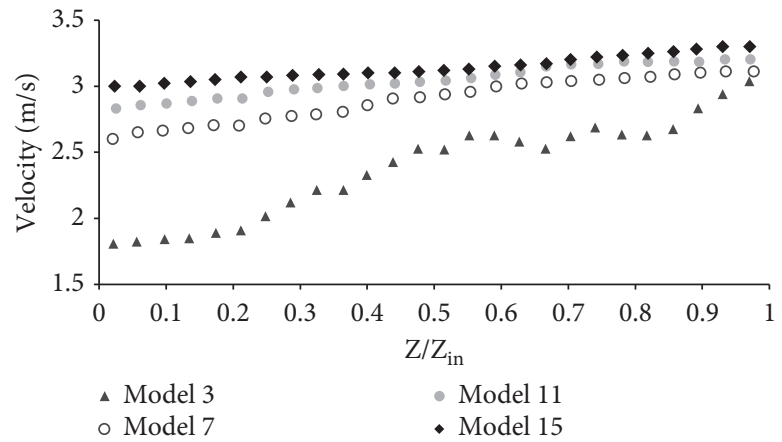

(c)

FIGURE 19: Comparison of velocity profiles with the same plant densities (depth $1 \mathrm{~m}$ ). Comparison of velocity profiles with (a) plant densities of $25 \%$, depth $1 \mathrm{~m}$; (b) plant densities of $50 \%$, depth $1 \mathrm{~m}$; and (c) plant densities of $75 \%$, depth $1 \mathrm{~m}$. 


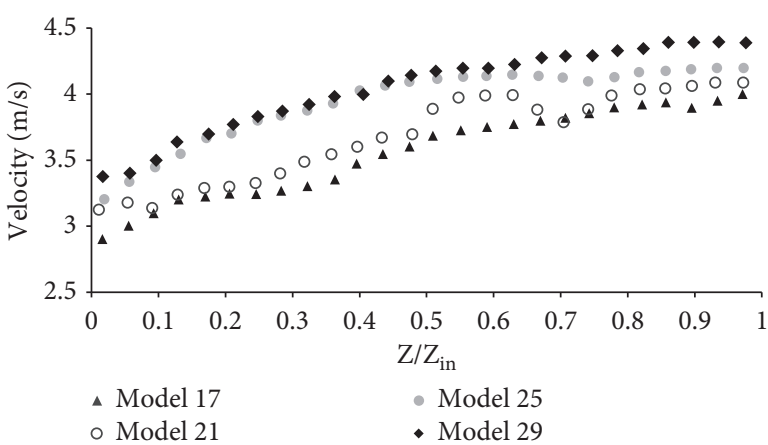

(a)

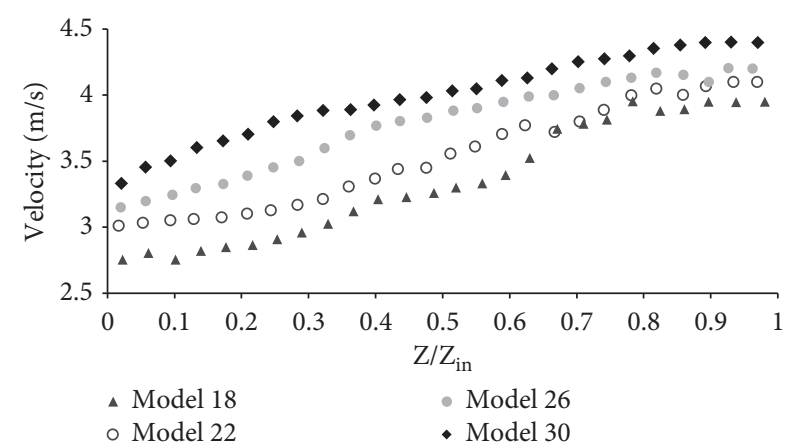

(b)

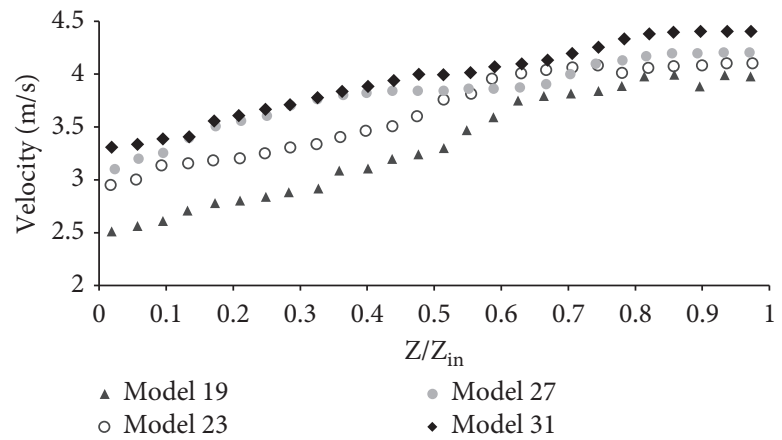

(c)

FIGURE 20: Comparison of velocity profiles with the same plant densities (depth $2 \mathrm{~m}$ ). Comparison of velocity profiles with (a) plant densities of $25 \%$, depth $2 \mathrm{~m}$; (b) plant densities of $50 \%$, depth $2 \mathrm{~m}$; and (c) plant densities of $75 \%$, depth $2 \mathrm{~m}$.

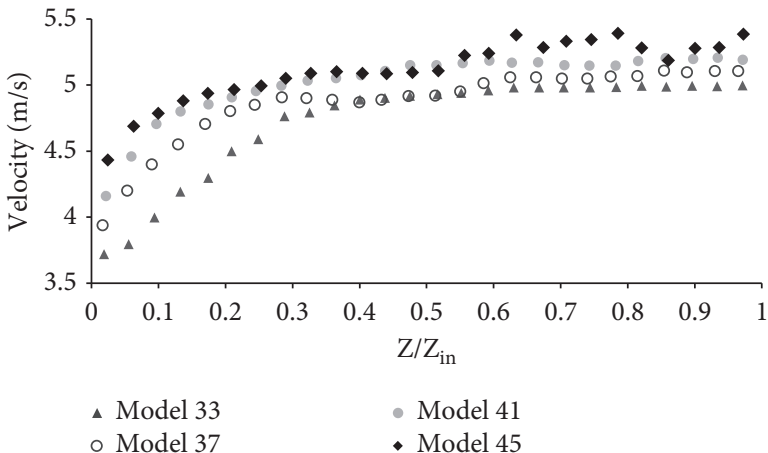

(a)

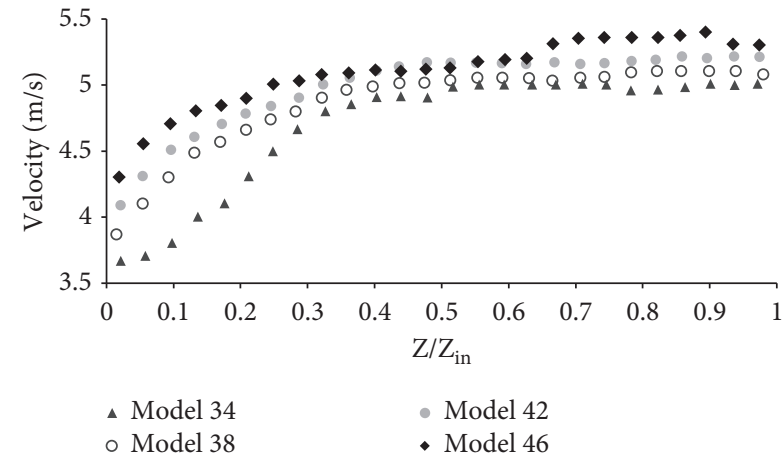

(b)

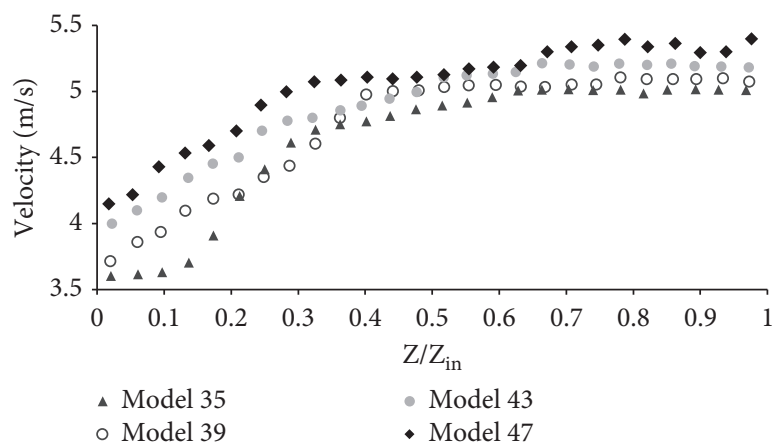

(c)

FIGURE 21: Comparison of velocity profiles with the same plant densities (depth $3 \mathrm{~m}$ ). Comparison of velocity profiles with (a) plant densities of $25 \%$, depth $3 \mathrm{~m}$; (b) plant densities of $50 \%$, depth $3 \mathrm{~m}$; and (c) plant densities of $75 \%$, depth $3 \mathrm{~m}$. 
simulation logic and software of this research for other domains such as power engineering [95-99].

\section{Conclusion}

The effects of vegetation on the flood canal were investigated by numerical modeling with FLOW-3D software. After analyzing the results, the following conclusions were reached:

(i) Increasing the density of vegetation reduces the velocity of the canal floor but has no effect on the velocity of the canal surface.

(ii) Increasing the Froude number is directly related to increasing the speed of the canal floor.

(iii) In the canal with a depth of one meter, a sudden increase in speed can be observed from the lowest speed and higher speed, which is justified by the sudden increase in Froude number.

(iv) As the inlet flow rate increases, the slope of the profiles from the bed to the water surface increases.

(v) By reducing the Froude number, the effect of vegetation on reducing the flow bed rate becomes more noticeable. And the input velocity in reducing the velocity of the canal floor does not have much effect.

(vi) At a flow rate between 3 and 3.3 meters per second due to the shallow depth of the canal and the higher landing number a more critical area is observed in which the flow bed velocity in this area is between 2.86 and $3.1 \mathrm{~m} / \mathrm{s}$.

(vii) Due to the critical flow velocity and the slight effect of the roughness of the horseshoe vortex floor, it is not visible and is only partially observed in models 1-2-3 and 21.

(viii) As the flow rate increases, the effect of vegetation on the rate of bed reduction decreases.

(ix) In conditions where less current intensity is passing, vegetation has a greater effect on reducing current intensity and energy consumption increases.

(x) In the case of using the flow rate of 0.8 cubic meters per second, the velocity distribution and flow regime show about $20 \%$ more energy consumption than in the case of using the flow rate of 1.3 cubic meters per second.

\section{Nomenclature}

$n$ : Manning's roughness coefficient

C: $\quad$ Chézy roughness coefficient

$f: \quad$ Darcy-Weisbach coefficient

$V: \quad$ Flow velocity

$R: \quad$ Hydraulic radius

g: $\quad$ Gravitational acceleration

$y$ : $\quad$ Flow depth

Ks: $\quad$ Bed roughness
A: $\quad$ Constant coefficient

$\mathrm{Re}^{*}$ : Reynolds number

$\partial y / \partial x$ : Depth of water change

$S_{0}$ : $\quad$ Slope of the canal floor

$S f: \quad$ Slope of energy line

Fr: $\quad$ Froude number

D: Characteristic length of the canal

G: Mass acceleration

$\tau$ : $\quad$ Shear stresses.

\section{Data Availability}

All data are included within the paper.

\section{Conflicts of Interest}

The authors declare that they have no conflicts of interest.

\section{Acknowledgments}

This work was partially supported by the National Natural Science Foundation of China under Contract no. 71761030 and Natural Science Foundation of Inner Mongolia under Contract no. 2019LH07003.

\section{References}

[1] H. Yu, L. Jie, W. Gui et al., "Dynamic Gaussian bare-bones fruit fly optimizers with abandonment mechanism: method and analysis," Engineering with Computers, vol. 20, pp. 1-29, 2020.

[2] X. Zhao, D. Li, B. Yang, C. Ma, Y. Zhu, and H. Chen, "Feature selection based on improved ant colony optimization for online detection of foreign fiber in cotton," Applied Soft Computing, vol. 24, pp. 585-596, 2014.

[3] J. Hu, H. Chen, A. A. Heidari et al., "Orthogonal learning covariance matrix for defects of grey wolf optimizer: insights, balance, diversity, and feature selection," Knowledge-Based Systems, vol. 213, Article ID 106684, 2021.

[4] C. Yu, M. Chen, K. Chen et al., "SGOA: annealing-behaved grasshopper optimizer for global tasks," Engineering with Computers, vol. 4, pp. 1-28, 2021.

[5] W. Shan, Z. Qiao, A. A. Heidari, H. Chen, H. Turabieh, and Y. Teng, "Double adaptive weights for stabilization of moth flame optimizer: balance analysis, engineering cases, and medical diagnosis," Knowledge-Based Systems, vol. 8, Article ID 106728, 2020.

[6] J. Tu, H. Chen, J. Liu et al., "Evolutionary biogeography-based whale optimization methods with communication structure: towards measuring the balance," Knowledge-Based Systems, vol. 212, Article ID 106642, 2021.

[7] Y. Zhang, R. Liu, X. Wang et al., “Towards augmented kernel extreme learning models for bankruptcy prediction: algorithmic behavior and comprehensive analysis," Neurocomputing, vol. 430, 2020.

[8] H.-L. Chen, G. Wang, C. Ma, Z.-N. Cai, W.-B. Liu, and S.-J. Wang, "An efficient hybrid kernel extreme learning machine approach for early diagnosis of Parkinson's disease," Neurocomputing, vol. 184, pp. 131-144, 2016.

[9] J. Xia, H. Chen, Q. Li et al., "Ultrasound-based differentiation of malignant and benign thyroid Nodules: an extreme 
learning machine approach," Computer Methods and Programs in Biomedicine, vol. 147, pp. 37-49, 2017.

[10] C. Li, L. Hou, B. Y. Sharma et al., "Developing a new intelligent system for the diagnosis of tuberculous pleural effusion," Computer Methods and Programs in Biomedicine, vol. 153, pp. 211-225, 2018.

[11] X. Xu and H.-L. Chen, "Adaptive computational chemotaxis based on field in bacterial foraging optimization," Soft Computing, vol. 18, no. 4, pp. 797-807, 2014.

[12] M. Wang, H. Chen, B. Yang et al., "Toward an optimal kernel extreme learning machine using a chaotic moth-flame optimization strategy with applications in medical diagnoses," Neurocomputing, vol. 267, pp. 69-84, 2017.

[13] L. Chao, K. Zhang, Z. Li, Y. Zhu, J. Wang, and Z. Yu, "Geographically weighted regression based methods for merging satellite and gauge precipitation," Journal of $\mathrm{Hy}$ drology, vol. 558, pp. 275-289, 2018.

[14] F. J. Golrokh, G. Azeem, and A. Hasan, "Eco-efficiency evaluation in cement industries: DEA malmquist productivity index using optimization models," ENG Transactions, vol. 1, 2020.

[15] D. Zhao, L. Lei, F. Yu et al., "Chaotic random spare ant colony optimization for multi-threshold image segmentation of 2D Kapur entropy," Knowledge-Based Systems, vol. 8, Article ID 106510, 2020

[16] Y. Zhang, R. Liu, X. Wang, H. Chen, and C. Li, "Boosted binary Harris hawks optimizer and feature selection," Engineering with Computers, vol. 517, pp. 1-30, 2020.

[17] L. Hu, G. Hong, J. Ma, X. Wang, and H. Chen, "An efficient machine learning approach for diagnosis of paraquat-poisoned patients," Computers in Biology and Medicine, vol. 59, pp. 116-124, 2015.

[18] L. Shen, H. Chen, Z. Yu et al., "Evolving support vector machines using fruit fly optimization for medical data classification," Knowledge-Based Systems, vol. 96, pp. 61-75, 2016.

[19] X. Zhao, X. Zhang, Z. Cai et al., "Chaos enhanced grey wolf optimization wrapped ELM for diagnosis of paraquat-poisoned patients," Computational Biology and Chemistry, vol. 78, pp. 481-490, 2019.

[20] Y. Xu, H. Chen, J. Luo, Q. Zhang, S. Jiao, and X. Zhang, "Enhanced Moth-flame optimizer with mutation strategy for global optimization," Information Sciences, vol. 492, pp. 181203, 2019.

[21] M. Wang and H. Chen, "Chaotic multi-swarm whale optimizer boosted support vector machine for medical diagnosis," Applied Soft Computing Journal, vol. 88, Article ID 105946, 2020.

[22] Y. Chen, J. Li, H. Lu, and P. Yan, "Coupling system dynamics analysis and risk aversion programming for optimizing the mixed noise-driven shale gas-water supply chains," Journal of Cleaner Production, vol. 278, Article ID 123209, 2020.

[23] H. Tang, Y. Xu, A. Lin et al., "Predicting green consumption behaviors of students using efficient firefly grey wolf-assisted K-nearest neighbor classifiers," IEEE Access, vol. 8, pp. 35546-35562, 2020.

[24] H.-J. Ma and G.-H. Yang, "Adaptive fault tolerant control of cooperative heterogeneous systems with actuator faults and unreliable interconnections," IEEE Transactions on Automatic Control, vol. 61, no. 11, pp. 3240-3255, 2015.

[25] H.-J. Ma and L.-X. Xu, "Decentralized adaptive fault-tolerant control for a class of strong interconnected nonlinear systems via graph theory," IEEE Transactions on Automatic Control, vol. $66,2020$.
[26] H. J. Ma, L. X. Xu, and G. H. Yang, "Multiple environment integral reinforcement learning-based fault-tolerant control for affine nonlinear systems," IEEE Transactions on Cybernetics, vol. 51, pp. 1-16, 2019.

[27] J. Hu, M. Wang, C. Zhao, Q. Pan, and C. Du, "Formation control and collision avoidance for multi-UAV systems based on Voronoi partition," Science China Technological Sciences, vol. 63, no. 1, pp. 65-72, 2020.

[28] C. Zhang, H. Li, Y. Qian, C. Chen, and X. Zhou, "Localityconstrained discriminative matrix regression for robust face identification," IEEE Transactions on Neural Networks and Learning Systems, vol. 99, pp. 1-15, 2020.

[29] X. Zhang, D. Wang, Z. Zhou, and Y. Ma, "Robust low-rank tensor recovery with rectification and alignment," IEEE Transactions on Pattern Analysis and Machine Intelligence, vol. 43, no. 1, pp. 238-255, 2019.

[30] X. Zhang, J. Wang, T. Wang, R. Jiang, J. Xu, and L. Zhao, "Robust feature learning for adversarial defense via hierarchical feature alignment," Information Sciences, vol. 560, 2020.

[31] X. Zhang, R. Jiang, T. Wang, and J. Wang, "Recursive neural network for video deblurring," IEEE Transactions on Circuits and Systems for Video Technology, vol. 03, p. 1, 2020.

[32] X. Zhang, T. Wang, J. Wang, G. Tang, and L. Zhao, "Pyramid channel-based feature attention network for image dehazing," Computer Vision and Image Understanding, vol. 197-198, Article ID 103003, 2020.

[33] X. Zhang, T. Wang, W. Luo, and P. Huang, "Multi-level fusion and attention-guided CNN for image dehazing," IEEE Transactions on Circuits and Systems for Video Technology, vol. 3, p. 1, 2020.

[34] L. He, J. Shen, and Y. Zhang, "Ecological vulnerability assessment for ecological conservation and environmental management," Journal of Environmental Management, vol. 206, pp. 1115-1125, 2018.

[35] Y. Chen, W. Zheng, W. Li, and Y. Huang, "Large group Activity security risk assessment and risk early warning based on random forest algorithm," Pattern Recognition Letters, vol. 144, pp. 1-5, 2021.

[36] J. Hu, H. Zhang, Z. Li, C. Zhao, Z. Xu, and Q. Pan, "Object traversing by monocular UAV in outdoor environment," Asian Journal of Control, vol. 25, 2020.

[37] P. Tian, H. Lu, W. Feng, Y. Guan, and Y. Xue, "Large decrease in streamflow and sediment load of Qinghai-Tibetan Plateau driven by future climate change: a case study in Lhasa River Basin," Catena, vol. 187, Article ID 104340, 2020.

[38] A. Stokes, C. Atger, A. G. Bengough, T. Fourcaud, and R. C. Sidle, "Desirable plant root traits for protecting natural and engineered slopes against landslides," Plant and Soil, vol. 324, no. 1, pp. 1-30, 2009.

[39] T. B. Devi, A. Sharma, and B. Kumar, "Studies on emergent flow over vegetative channel bed with downward seepage," Hydrological Sciences Journal, vol. 62, no. 3, pp. 408-420, 2017.

[40] G. Ireland, M. Volpi, and G. Petropoulos, "Examining the capability of supervised machine learning classifiers in extracting flooded areas from Landsat TM imagery: a case study from a Mediterranean flood," Remote Sensing, vol. 7, no. 3, pp. 3372-3399, 2015.

[41] L. Goodarzi and S. Javadi, "Assessment of aquifer vulnerability using the DRASTIC model; a case study of the DezfulAndimeshk Aquifer," Computational Research Progress in Applied Science \& Engineering, vol. 2, no. 1, pp. 17-22, 2016.

[42] K. Zhang, Q. Wang, L. Chao et al., "Ground observationbased analysis of soil moisture spatiotemporal variability 
across a humid to semi-humid transitional zone in China," Journal of Hydrology, vol. 574, pp. 903-914, 2019.

[43] L. De Doncker, P. Troch, R. Verhoeven, K. Bal, P. Meire, and J. Quintelier, "Determination of the Manning roughness coefficient influenced by vegetation in the river $A a$ and Biebrza river," Environmental Fluid Mechanics, vol. 9, no. 5, pp. 549-567, 2009.

[44] M. Fathi-Moghadam and K. Drikvandi, "Manning roughness coefficient for rivers and flood plains with non-submerged vegetation," International Journal of Hydraulic Engineering, vol. 1, no. 1, pp. 1-4, 2012.

[45] F.-C. Wu, H. W. Shen, and Y.-J. Chou, "Variation of roughness coefficients for unsubmerged and submerged vegetation," Journal of Hydraulic Engineering, vol. 125, no. 9, pp. 934-942, 1999.

[46] M. K. Wood, "Rangeland vegetation-hydrologic interactions," in Vegetation Science Applications for Rangeland Analysis and Managementvol. 3, , pp. 469-491, Springer, 1988.

[47] C. Wilson, O. Yagci, H.-P. Rauch, and N. Olsen, "3D numerical modelling of a willow vegetated river/floodplain system," Journal of Hydrology, vol. 327, no. 1-2, pp. 13-21, 2006.

[48] R. Yazarloo, M. Khamehchian, and M. R. Nikoodel, "Observational-computational $3 \mathrm{~d}$ engineering geological model and geotechnical characteristics of young sediments of golestan province," Computational Research Progress in Applied Science \& Engineering (CRPASE), vol. 03, 2017.

[49] G. E. Freeman, W. H. Rahmeyer, and R. R. Copeland, "Determination of resistance due to shrubs and woody vegetation," International Journal of River Basin Management, vol. 19, 2000.

[50] N. Kouwen and T. E. Unny, "Flexible roughness in open channels," Journal of the Hydraulics Division, vol. 99, no. 5, pp. 713-728, 1973.

[51] S. Hosseini and J. Abrishami, Open Channel Hydraulics, Elsevier, Amsterdam, Netherlands, 2007.

[52] C. S. James, A. L. Birkhead, A. A. Jordanova, and J. J. O’Sullivan, "Flow resistance of emergent vegetation," Journal of Hydraulic Research, vol. 42, no. 4, pp. 390-398, 2004.

[53] F. Huthoff and D. Augustijn, "Channel roughness in 1D steady uniform flow: Manning or Chézy?," NCR-days, vol. 102, 2004.

[54] M. S. Sabegh, M. Saneie, M. Habibi, A. A. Abbasi, and M. Ghadimkhani, "Experimental investigation on the effect of river bank tree planting array, on shear velocity," Journal of Watershed Engineering and Management, vol. 2, no. 4, 2011.

[55] A. Errico, V. Pasquino, M. Maxwald, G. B. Chirico, L. Solari, and F. Preti, "The effect of flexible vegetation on flow in drainage channels: estimation of roughness coefficients at the real scale," Ecological Engineering, vol. 120, pp. 411-421, 2018.

[56] S. E. Darby, "Effect of riparian vegetation on flow resistance and flood potential," Journal of Hydraulic Engineering, vol. 125, no. 5, pp. 443-454, 1999.

[57] V. Kutija and H. Thi Minh Hong, "A numerical model for assessing the additional resistance to flow introduced by flexible vegetation," Journal of Hydraulic Research, vol. 34, no. 1, pp. 99-114, 1996.

[58] T. Fischer-Antze, T. Stoesser, P. Bates, and N. R. B. Olsen, “3D numerical modelling of open-channel flow with submerged vegetation," Journal of Hydraulic Research, vol. 39, no. 3, pp. 303-310, 2001.
[59] U. Stephan and D. Gutknecht, "Hydraulic resistance of submerged flexible vegetation," Journal of Hydrology, vol. 269, no. 1-2, pp. 27-43, 2002.

[60] F. G. Carollo, V. Ferro, and D. Termini, "Flow resistance law in channels with flexible submerged vegetation," Journal of Hydraulic Engineering, vol. 131, no. 7, pp. 554-564, 2005.

[61] W. Fu-sheng, "Flow resistance of flexible vegetation in open channel," Journal of Hydraulic Engineering, vol. S1, 2007.

[62] P.-f. Wang, C. Wang, and D. Z. Zhu, "Hydraulic resistance of submerged vegetation related to effective height," Journal of Hydrodynamics, vol. 22, no. 2, pp. 265-273, 2010.

[63] J. K. Lee, L. C. Roig, H. L. Jenter, and H. M. Visser, "Drag coefficients for modeling flow through emergent vegetation in the Florida Everglades," Ecological Engineering, vol. 22, no. 45, pp. 237-248, 2004.

[64] G. J. Arcement and V. R. Schneider, Guide for Selecting Manning's Roughness Coefficients for Natural Channels and Flood Plains, US Government Printing Office, Washington, DC, USA, 1989.

[65] Y. Ding and S. S. Y. Wang, "Identification of Manning's roughness coefficients in channel network using adjoint analysis," International Journal of Computational Fluid Dynamics, vol. 19, no. 1, pp. 3-13, 2005.

[66] E. T. Engman, "Roughness coefficients for routing surface runoff," Journal of Irrigation and Drainage Engineering, vol. 112, no. 1, pp. 39-53, 1986.

[67] M. Feizbahr, C. Kok Keong, F. Rostami, and M. Shahrokhi, "Wave energy dissipation using perforated and non perforated piles," International Journal of Engineering, vol. 31, no. 2, pp. 212-219, 2018.

[68] M. Farzadkhoo, A. Keshavarzi, H. Hamidifar, and M. Javan, "Sudden pollutant discharge in vegetated compound meandering rivers," Catena, vol. 182, Article ID 104155, 2019.

[69] V. T. Chow, Open-channel Hydraulics, Mcgraw-Hill Civil Engineering Series, Chennai, TN, India, 1959.

[70] X. Zhang, R. Jing, Z. Li, Z. Li, X. Chen, and C.-Y. Su, "Adaptive pseudo inverse control for a class of nonlinear asymmetric and saturated nonlinear hysteretic systems," IEEE/CAA Journal of Automatica Sinica, vol. 8, no. 4, pp. 916-928, 2020.

[71] C. Zuo, Q. Chen, L. Tian, L. Waller, and A. Asundi, "Transport of intensity phase retrieval and computational imaging for partially coherent fields: the phase space perspective," Optics and Lasers in Engineering, vol. 71, pp. 20-32, 2015.

[72] C. Zuo, J. Sun, J. Li, J. Zhang, A. Asundi, and Q. Chen, "Highresolution transport-of-intensity quantitative phase microscopy with annular illumination," Scientific Reports, vol. 7, no. 1, pp. 7654-7722, 2017.

[73] B.-H. Li, Y. Liu, A.-M. Zhang, W.-H. Wang, and S. Wan, “A survey on blocking technology of entity resolution," Journal of Computer Science and Technology, vol. 35, no. 4, pp. 769-793, 2020.

[74] Y. Liu, B. Zhang, Y. Feng et al., "Development of $340-\mathrm{GHz}$ transceiver front end based on GaAs monolithic integration technology for THz active imaging array," Applied Sciences, vol. 10, no. 21, p. 7924, 2020.

[75] J. Hu, H. Zhang, L. Liu, X. Zhu, C. Zhao, and Q. Pan, "Convergent multiagent formation control with collision avoidance," IEEE Transactions on Robotics, vol. 36, no. 6, pp. 1805-1818, 2020.

[76] M. B. Movahhed, J. Ayoubinejad, F. N. Asl, and M. Feizbahr, "The effect of rain on pedestrians crossing speed," Computational Research Progress in Applied Science \& Engineering (CRPASE), vol. 6, no. 3, 2020. 
[77] A. Li, D. Spano, J. Krivochiza et al., "A tutorial on interference exploitation via symbol-level precoding: overview, state-ofthe-art and future directions," IEEE Communications Surveys \& Tutorials, vol. 22, no. 2, pp. 796-839, 2020.

[78] W. Zhu, C. Ma, X. Zhao et al., "Evaluation of sino foreign cooperative education project using orthogonal sine cosine optimized kernel extreme learning machine," IEEE Access, vol. 8, pp. 61107-61123, 2020.

[79] G. Liu, W. Jia, M. Wang et al., "Predicting cervical hyperextension injury: a covariance guided sine cosine support vector machine," IEEE Access, vol. 8, pp. 46895-46908, 2020.

[80] Y. Wei, H. Lv, M. Chen et al., "Predicting entrepreneurial intention of students: an extreme learning machine with Gaussian barebone harris hawks optimizer," IEEE Access, vol. 8, pp. 76841-76855, 2020.

[81] A. Lin, Q. Wu, A. A. Heidari et al., "Predicting intentions of students for master programs using a chaos-induced sine cosine-based fuzzy K-Nearest neighbor classifier," Ieee Access, vol. 7, pp. 67235-67248, 2019.

[82] Y. Fan, P. Wang, A. A. Heidari et al., "Rationalized fruit fly optimization with sine cosine algorithm: a comprehensive analysis," Expert Systems with Applications, vol. 157, Article ID 113486, 2020.

[83] E. Rodríguez-Esparza, L. A. Zanella-Calzada, D. Oliva et al., "An efficient Harris hawks-inspired image segmentation method," Expert Systems with Applications, vol. 155, Article ID 113428, 2020.

[84] S. Jiao, G. Chong, C. Huang et al., "Orthogonally adapted Harris hawks optimization for parameter estimation of photovoltaic models," Energy, vol. 203, Article ID 117804, 2020.

[85] Z. Xu, Z. Hu, A. A. Heidari et al., "Orthogonally-designed adapted grasshopper optimization: a comprehensive analysis," Expert Systems with Applications, vol. 150, Article ID 113282, 2020.

[86] A. Abbassi, R. Abbassi, A. A. Heidari et al., "Parameters identification of photovoltaic cell models using enhanced exploratory salp chains-based approach," Energy, vol. 198, Article ID 117333, 2020.

[87] M. Mahmoodi and K. K. Aminjan, "Numerical simulation of flow through sukhoi 24 air inlet," Computational Research Progress in Applied Science \& Engineering (CRPASE), vol. 03, 2017.

[88] F. J. Golrokh and A. Hasan, "A comparison of machine learning clustering algorithms based on the DEA optimization approach for pharmaceutical companies in developing countries," ENG Transactions, vol. 1, 2020.

[89] H. Chen, A. A. Heidari, H. Chen, M. Wang, Z. Pan, and A. H. Gandomi, "Multi-population differential evolutionassisted Harris hawks optimization: framework and case studies," Future Generation Computer Systems, vol. 111, pp. 175-198, 2020.

[90] J. Guo, H. Zheng, B. Li, and G.-Z. Fu, "Bayesian hierarchical model-based information fusion for degradation analysis considering non-competing relationship," IEEE Access, vol. 7, pp. 175222-175227, 2019.

[91] J. Guo, H. Zheng, B. Li, and G.-Z. Fu, “A Bayesian approach for degradation analysis with individual differences," IEEE Access, vol. 7, pp. 175033-175040, 2019.

[92] M. M. A. Malakoutian, Y. Malakoutian, P. Mostafapour, and S. Z. D. Abed, "Prediction for monthly rainfall of six meteorological regions and TRNC (case study: north Cyprus)," ENG Transactions, vol. 2, no. 2, 2021.
[93] H. Arslan, M. Ranjbar, and Z. Mutlum, "Maximum sound transmission loss in multi-chamber reactive silencers: are two chambers enough?," ENG Transactions, vol. 2, no. 1, 2021.

[94] N. Tonekaboni, M. Feizbahr, N. Tonekaboni, G.-J. Jiang, and H.-X. Chen, "Optimization of solar CCHP systems with collector enhanced by porous media and nanofluid," Mathematical Problems in Engineering, vol. 2021, Article ID 9984840, 12 pages, 2021.

[95] Z. Niu, B. Zhang, J. Wang et al., "The research on $220 \mathrm{GHz}$ multicarrier high-speed communication system," China Communications, vol. 17, no. 3, pp. 131-139, 2020.

[96] B. Zhang, Z. Niu, J. Wang et al., "Four-hundred gigahertz broadband multi-branch waveguide coupler," IET Microwaves, Antennas \& Propagation, vol. 14, no. 11, pp. 1175-1179, 2020.

[97] Z.-Q. Niu, L. Yang, B. Zhang et al., "A mechanical reliability study of $3 \mathrm{~dB}$ waveguide hybrid couplers in the submillimeter and terahertz band," Journal of Zhejiang University Science, vol. 1, no. 1, 1998.

[98] B. Zhang, D. Ji, D. Fang, S. Liang, Y. Fan, and X. Chen, “A novel $220-\mathrm{GHz} \mathrm{GaN}$ diode on-chip tripler with high driven power," IEEE Electron Device Letters, vol. 40, no. 5, pp. 780-783, 2019.

[99] M. Taleghani and A. Taleghani, "Identification and ranking of factors affecting the implementation of knowledge management engineering based on TOPSIS technique," ENG Transactions, vol. 1, no. 1, 2020. 